Columbia Basin Ground Water Management Area

\title{
Summary of Nitrate Concentrations in Ground Water of Adams, Franklin, and Grant Counties, Washington, Fall 1998--A Baseline for Future Trend Analysis
}

Water-Resources Investigations Report 99-4288

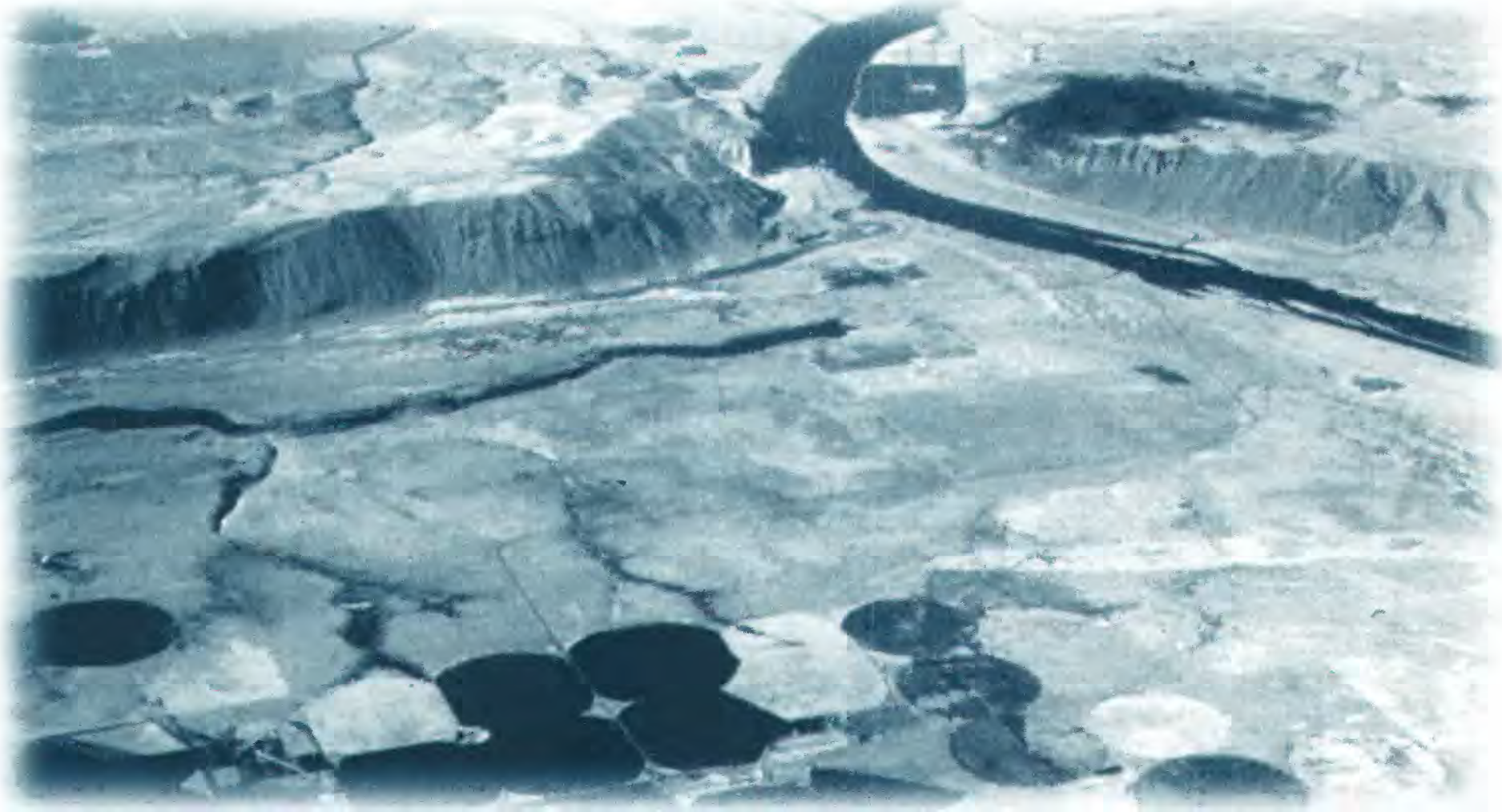


Cover - Photo of irrigated agriculture in the Columbia Plateau, Washington, by Denzel R. Cline, U.S. Geological Survey, retired. 


\section{Summary of Nitrate Concentrations in Ground Water of Adams, Franklin, and Grant Counties, Washington, Fall 1998--A Baseline for Future Trend Analysis}

By SARAH J. RYKER and LONNA M. FRANS

U.S. GEOLOGICAL SURVEY

Water-Resources Investigations Report 99-4288

Prepared in cooperation with the COLUMBIA BASIN GROUND WATER MANAGEMENT AREA 


\section{U.S. DEPARTMENT OF THE INTERIOR \\ BRUCE BABBITT, Secretary}

U.S. GEOLOGICAL SURVEY

Charles G. Groat, Director

The use of firm, trade, and brand names in this report is for identification purposes only and does not constitute endorsement by the U.S. Geological Survey.

For additional information write to:

Copies of this report can be purchased from:

District Chief

U.S. Geological Survey

1201 Pacific Avenue, Suite 600

Tacoma, Washington 98402
U.S. Geological Survey

Information Services

Box 25286

Federal Center

Denver, CO 80225 


\section{CONTENTS}

Abstract

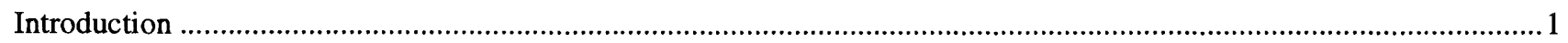

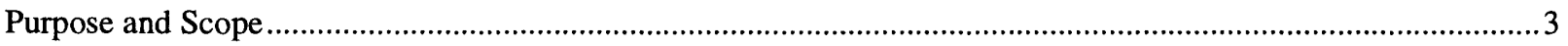

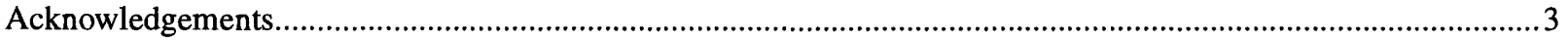

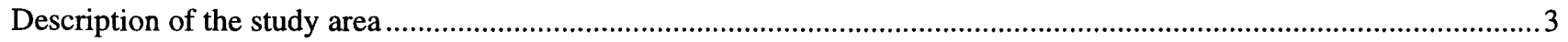

Collection of data for the baseline dataset...............................................................................................................

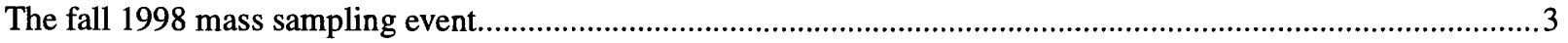

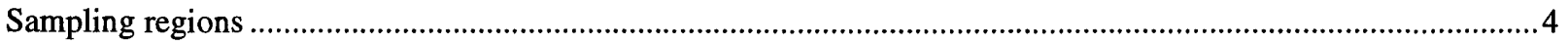

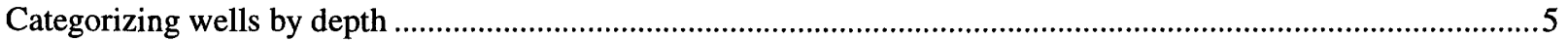

Laboratory analytical methods ...................................................................................................................

Summary of baseline nitrate concentrations.................................................................................................................. 10

Comparison of Concentrations within the Ground Water Management Area..............................................................10

Additional considerations in calculating baseline statistics .....................................................................................14

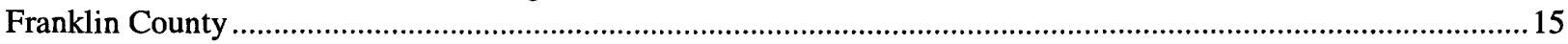

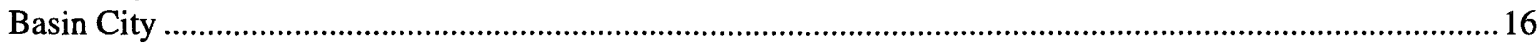

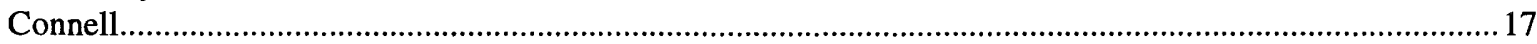

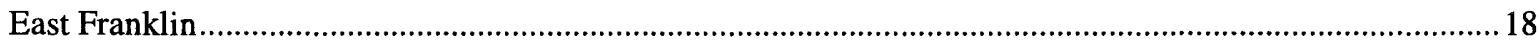

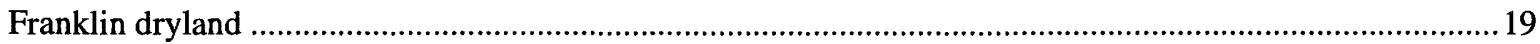

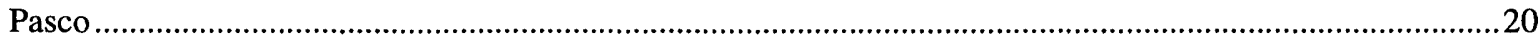

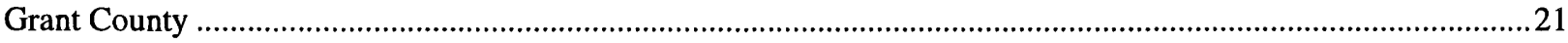

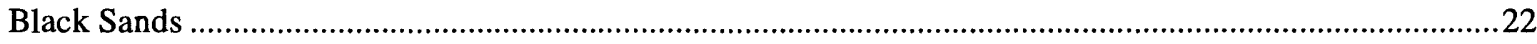

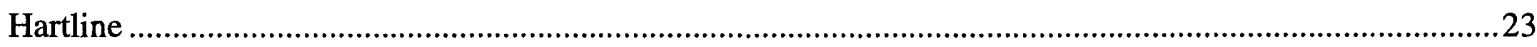

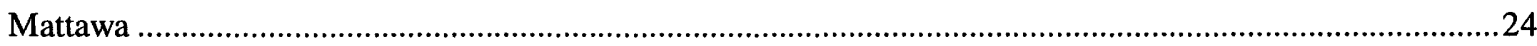

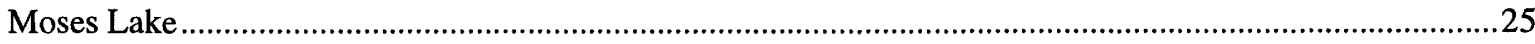

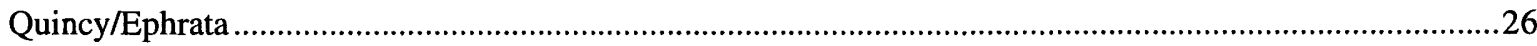

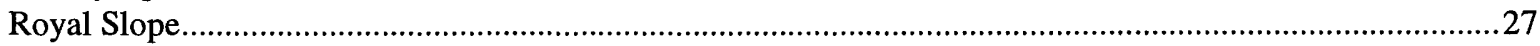

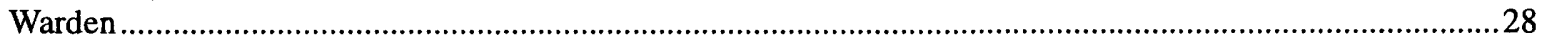

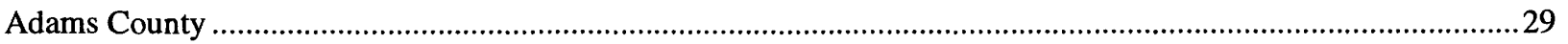

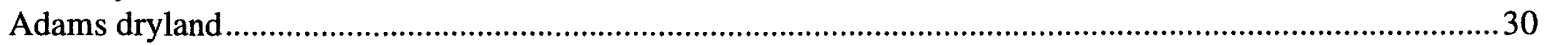

Deep well irrigators ……………………………………………………………………………………….

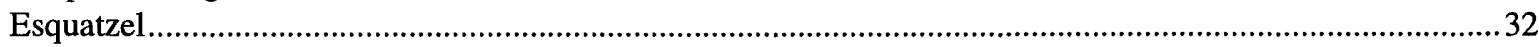

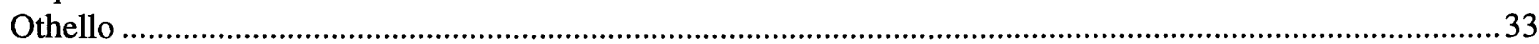

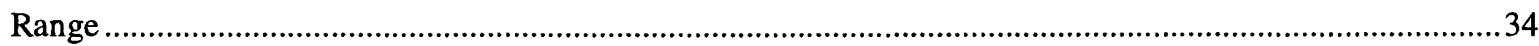

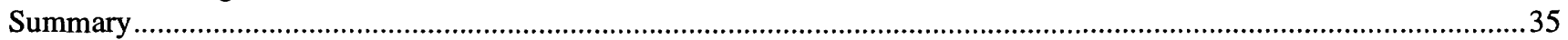

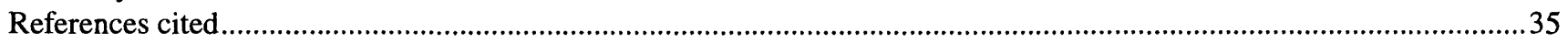

Appendix A--Results of quality-assurance sampling and analysis .....................................................................................

\section{Figures}

1. Map showing location of the Columbia Basin Ground Water Management Area,

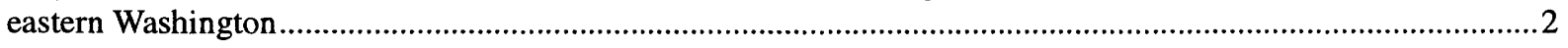

2. Graph showing numbers of wells sampled in different water use categories..........................................................

3. Map showing locations and ranges of nitrate concentrations of the 574 wells sampled during fall 1998

4. Map showing the percentage of samples exceeding the U.S. Environmental Protection Agency maximum contaminant level (MCL) for nitrate in drinking water for each sampling region and the category of well depths sampled.... 
5a. Boxplots showing the distribution of nitrate concentrations for groups of wells sampled across the Ground Water Management Area

5b. Graph showing concentrations of nitrate in sampled wells, with lines representing moving 50th, 75th, and 90th percentiles of concentration for varying depths.

6. Map showing sampling region boundaries in Franklin County

7-12. Boxplots and graphs showing (a) the distribution of nitrate concentrations for groups of wells sampled, and (b) concentrations of nitrate in sampled wells, with lines representing moving 50th, 75th, and 90th percentiles of concentration for varying depths (where sufficient data are available) for:

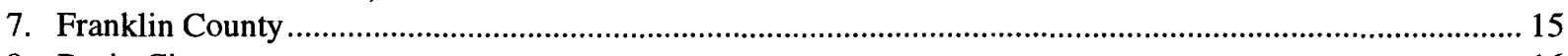

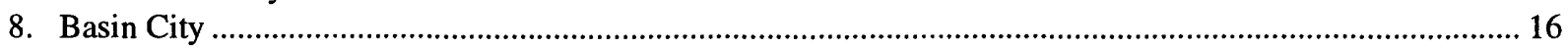

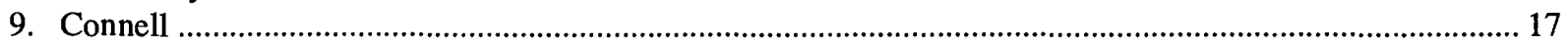

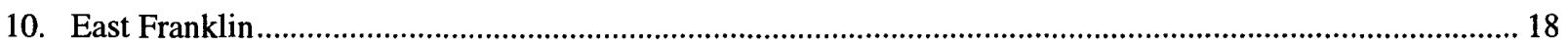

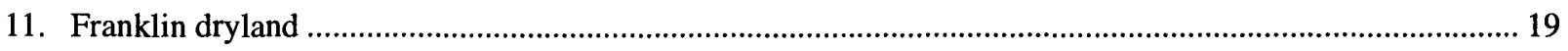

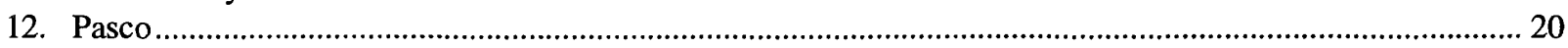

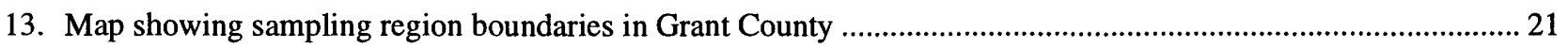

14-21. Boxplots and graphs showing (a) the distribution of nitrate concentrations for groups of wells sampled, and (b) concentrations of nitrate in sampled wells, with lines representing moving 50th, 75th, and 90th percentiles of concentration for varying depths (where sufficient data are available) for:

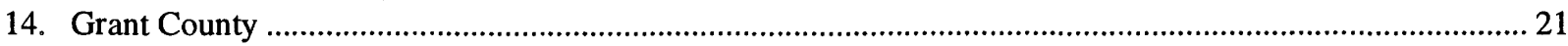

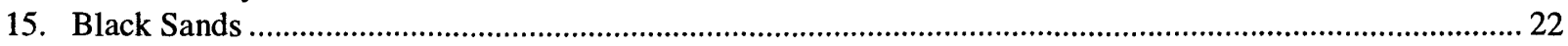

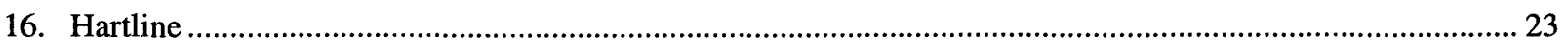

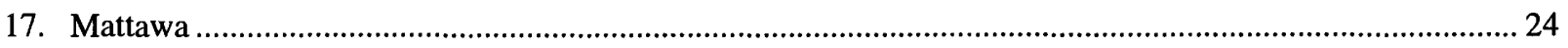

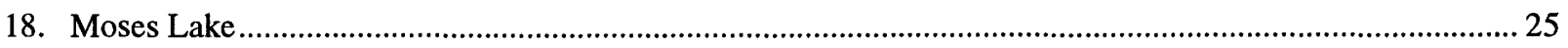

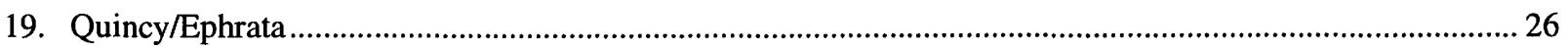

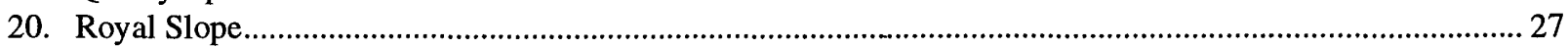

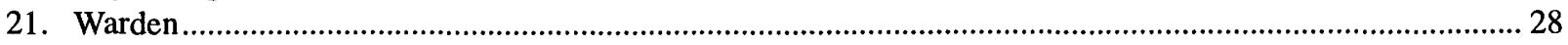

22. Map showing sampling region boundaries in Adams County ..........................................................................29

23-28. Boxplots and graphs showing (a) the distribution of nitrate concentrations for groups of wells sampled, and (b) concentrations of nitrate in sampled wells, with lines representing moving 50th, 75th, and 90th percentiles of concentration for varying depths (where sufficient data are available) for:

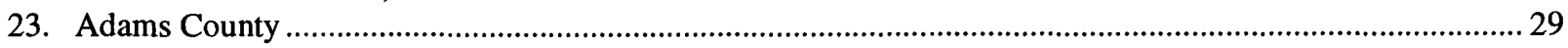

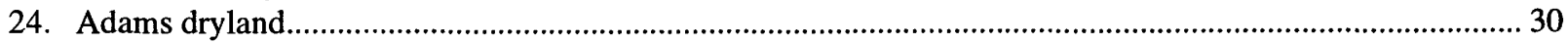

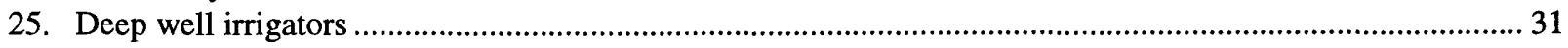

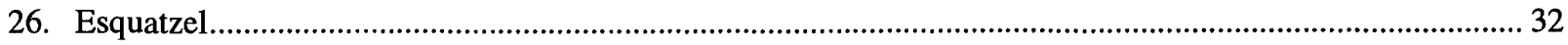

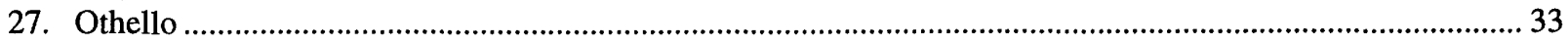

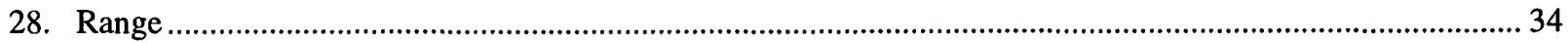

Tables

1. Descriptions and areas of sampling regions

2. Existing information on wells sampled in the fall mass sampling and all wells in the GWMA study area from information stored in the National Water Information System .................................. 8

3. Depth categories used to select wells for sampling in each sampling region...................................................... 8

4. Percentage of samples exceeding the U.S. Environmental Protection Agency maximum contaminant level for nitrate for each county and category of well depths sampled.............................................. 10

5. Summary of nitrate concentrations in the Columbia Basin GWMA area .......................................................... 11

6. Median concentrations of nitrate found in each sampling region, ranked in descending order of concentration.

7-26. Summary of nitrate concentrations in ground water, :

7. Franklin County.

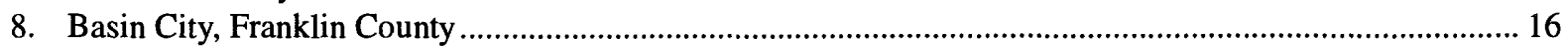

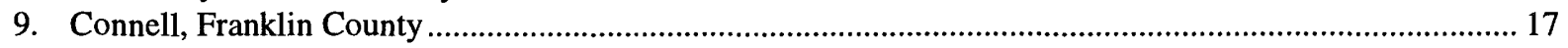




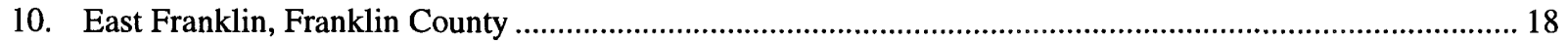

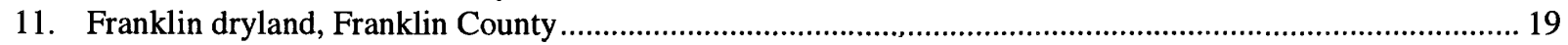

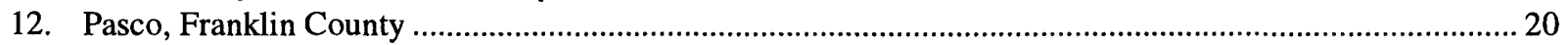

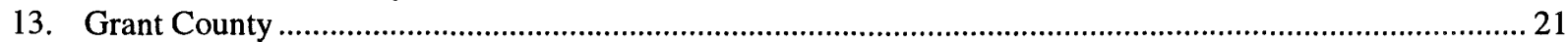

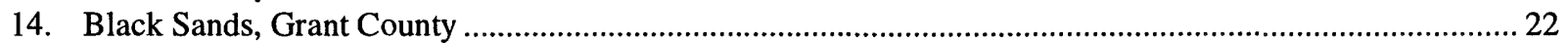

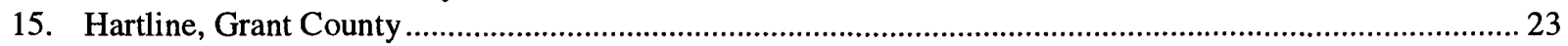

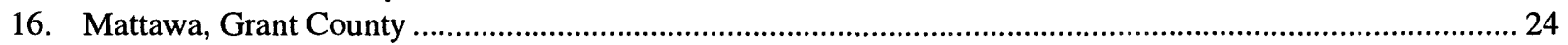

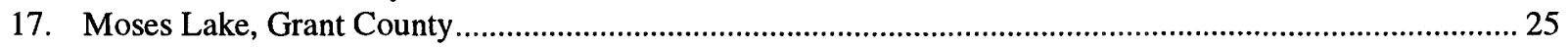

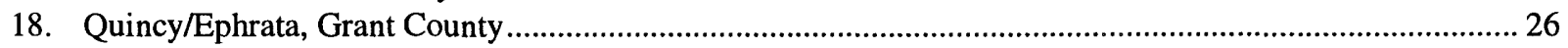

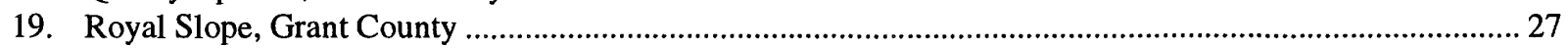

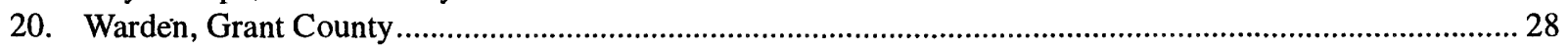

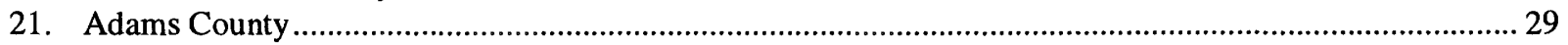

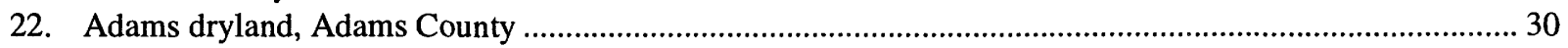

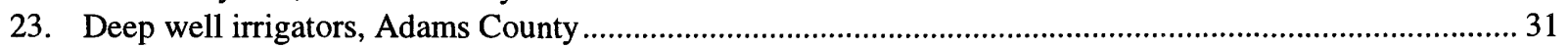

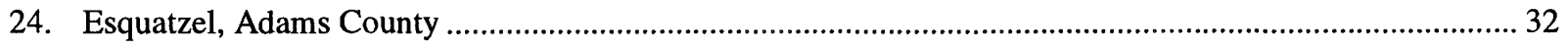

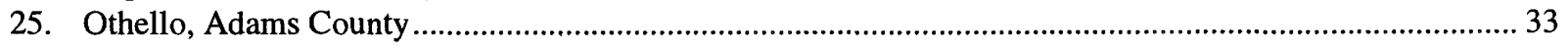

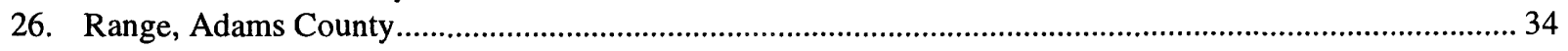

A1. Nitrate concentrations reported for split samples of well water ..................................................................... 38

A2. Nitrate concentrations reported for split samples of reference solutions .......................................................... 39 


\section{SUMMARY OF NITRATE CONCENTRATIONS IN GROUND WATER OF ADAMS, FRANKLIN, AND GRANT COUNTIES, WASHINGTON, FALL 1998--A BASELINE FOR FUTURE TREND ANALYSIS}

\author{
By Sarah J. Ryker and Lonna M. Frans
}

\section{ABSTRACT}

Since the early 1950 's, nitrate concentrations in ground water in some areas of the Columbia Basin, eastern Washington, have increased greatly. At present, over 20 percent of sampled wells have nitrate concentrations exceeding drinking water standards.

The Columbia Basin Ground Water Management Area (GWMA) was formed in February 1998 with the goal of reducing nitrate concentrations in ground water in Adams, Franklin, and Grant Counties. As part of the GWMA characterization and monitoring program, 574 wells in Adams, Franklin, and Grant Counties were sampled for nitrate in the fall of 1998 by the GWMA. These wells serve as a baseline dataset of current nitrate concentrations in ground water in the GWMA area and provide a basis for further research into agricultural practices and natural influences.

Summary statisitics were examined for 17 sampling regions within the three-county area as well as the relation between nitrate concentration and well depth. The summary statistics were computed for different ranges of well depths in each sampling region. Overall, 23 percent of the samples exceeded the U.S. Environmental Protection Agency maximum contaminant level (MCL) of 10 milligrams per liter. An additional 37 percent of the samples had nitrate concentrations between 3 and 10 milligrams per liter, constituting a large group of wells with elevated concentrations of nitrate. In Franklin County, 30 percent of the samples exceeded the MCL, while approximately 20 percent of the samples in both Grant and Adams Counties exceeded the MCL.

\section{INTRODUCTION}

Over 80 percent of drinking water in the Columbia Basin, eastern Washington, comes from ground water. Since the early 1950 's, nitrate concentrations in ground water in some areas of the Columbia Basin have increased by as much as two orders of magnitude (Ebbert and others, 1995). Previous studies (Ebbert and others, 1995; Jones and Wagner, 1995; Ryker and Jones, 1995; Washington State Interagency Ground Water Committee, 1996) have found that nitrate concentrations in approximately 20 percent of all wells in the Columbia Basin exceed or exceeded the Environmental Protection Agency (EPA) maximum contaminant level (MCL) of $10 \mathrm{mg} / \mathrm{L}$ (milligrams per liter) of nitrate as $\mathrm{N}$ in drinking water. These studies generally relied on existing data from a variety of periods or described only part of the area of the Columbia Basin.

In February 1998, the Washington State Department of Ecology (WDOE) approved the formation of the Columbia Basin Ground Water Management Area (GWMA) in Adams, Franklin, and Grant Counties, which are in the central part of the Columbia Basin (fig. 1). The initial emphasis of the GWMA is on the reduction of nitrate concentrations in ground water (Columbia GWMA steering committee, 31 October 1997). The first 3 years of the GWMA program include four components:

- Plan development and administration

- Ground-water characterization and monitoring

- Public information and education

- Implementation and research

Ground-water characterization and monitoring for the GWMA are being carried out by a partnership of the U.S. Geological Survey and a private consultant (Kennedy/Jenks Consultants, Federal Way, Wash.), with the common purpose of producing scientific products supporting the overall Columbia Basin GWMA effort to minimize nitrate concentrations in 


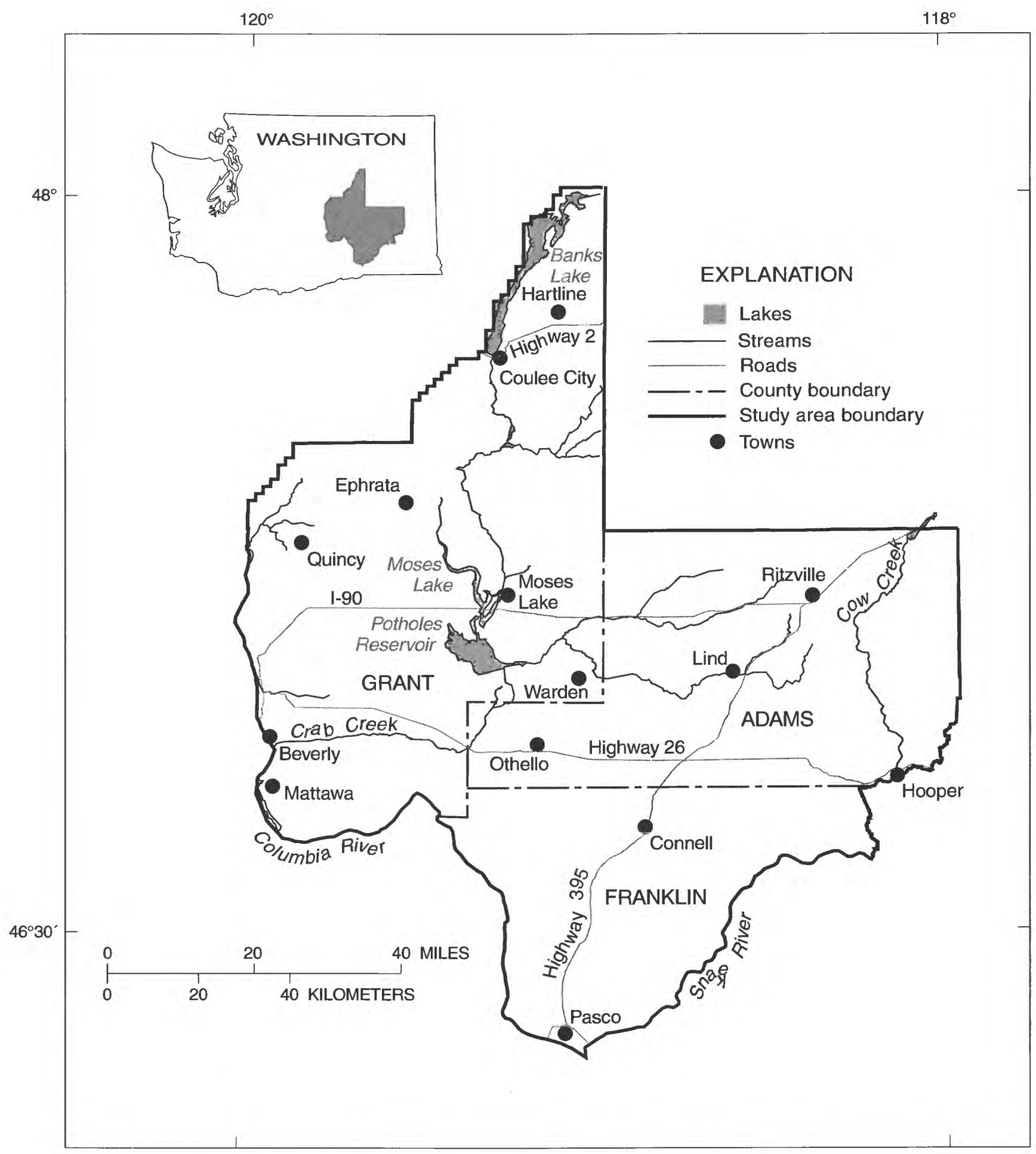

Figure 1. Location of the Columbia Basin Ground Water Management Area, eastern Washington. 
ground water (Columbia Basin GWMA Characterization and Monitoring Workgroup, 23 April 1998). To help meet this goal, the USGS will:

- determine nitrate concentrations in the shallow and deep regional ground-water systems of Adams, Franklin, and Grant Counties in eastern Washington;

- correlate the major factors influencing nitrate concentrations to produce a more detailed and quantitative analysis of the risk of elevated nitrate concentrations than is currently available for the study area; and

- develop a long-term monitoring plan to identify temporal trends in regional nitrate concentrations in ground water and the potential impact of such trends on future availability of low-nitrate drinking water.

As part of the GWMA characterization and monitoring program, 574 wells in Adams, Franklin, and Grant Counties were sampled for nitrate in the fall of 1998. This dataset serves as a baseline of current nitrate concentrations in ground water in the GWMA area and provides a basis for further research into agricultural practices and natural influences. Based on this dataset, the purpose of this report is to publish summary statistics describing current concentrations of nitrate in ground water of the Columbia Basin for different geographic areas and ranges of depths.

\section{Purpose and Scope}

This report is intended to present a snapshot of nitrate concentrations at varying depths and locations to serve as a baseline for future trend analysis and, secondarily, a comparison between areas and depth zones. This report provides information to meet the first objective of the USGS participation in the GWMA study by publishing summary statistics describing the current baseline concentrations of nitrate in ground water in different geographic areas and ranges of well depths.

\section{Acknowledgments}

The authors acknowledge the substantial contributions of Viki Leuba, Charles Pitz, Deanna Clarkson, Chris Cook, Jennifer Brunty, Pat Daly, and all the ground-water sampling teams from the Conservation and Health districts of Adams, Grant, and Franklin Counties. This report would not have been possible without their hard work.

\section{DESCRIPTION OF THE STUDY AREA}

The Columbia Basin Ground Water Management Area (fig. 1) includes Adams, Franklin, and Grant Counties in eastern Washington, encompassing an area of $5,985 \mathrm{mi}^{2}\left(15,501 \mathrm{~km}^{2}\right)$, with a population of approximately 150,000 . The climate is arid to semiarid, with average annual precipitation ranging from 6 to 13 inches per year. Franklin County is bordered by the Columbia River to the west and by the Snake River to the south and east, Grant County is bordered by the Columbia River to the west, and Adams County is bordered by Grant County to the west and Franklin County to the south. The subsurface of the GWMA area is dominated by sediments of varying thickness that overlie basalt. The Columbia Basin is one of the Nation's top two producers of potatoes and wheat and is a significant producer of apples and many specialty crops. Much of the southeastern part of the GWMA study area is intensively irrigated with Columbia River water, while other parts of the GWMA area are dominated by dryland or ground-water-irrigated farming and rangeland grazing. Since the start of surface-water irrigation in the 1950's, the water table in some parts of the GWMA area has risen by 50 to 500 feet.

\section{COLLECTION OF DATA FOR THE BASELINE DATASET}

\section{The Fall 1998 Mass Sampling Event}

The first major step in the characterization and monitoring process was the completion of a mass sampling for nitrate in the fall of 1998 . Between September and November 1998, 574 wells in Adams, 
Franklin, and Grant Counties were sampled for nitrate by the GWMA stakeholder agencies (primarily conservation districts and health districts). Results of the sampling create a more current, consistent, and detailed three-dimensional picture of the distribution of nitrate concentrations than has been available in the past.

The sampling results also provide a starting point for setting priorities and development of a ground-water management plan, for smaller-scale research, for investigations into sources of nitrogen and transport mechanisms, and for development and implementation of best management practices (BMP's) for application of fertilizers and irrigation water. Finally, the mass sampling permitted the creation of a baseline dataset against which future sampling results may be compared.

In designing the mass sampling event, two primary considerations determined much of the selection of wells. In order to obtain as unbiased a dataset as possible and one that could be interpreted as broadly representative of conditions in the GWMA area, it was necessary to select a random group of wells for sampling. In addition, it was important to represent a variety of hydrologic and water-quality conditions, both at the land surface and below it. Satisfying these requirements required two interpretive components: the delineation of surface regions for sampling and the creation of categories of wells to represent subsurface conditions. Based on these sampling regions and categories, the use of USGS Stratified Random SiteSelection software (Scott, 1990) within a geographic information system ensured an areally random selection of wells for sampling. The mass sampling was designed to try to collect a high enough number of samples (approximately 20 for each sampling region and subsurface category) to allow the computation of summary statistics while remaining within the budget and time constraint of the project.

Well selection for the fall 1998 sampling, and the samplers' success in obtaining access to the selected wells, was constrained by the limited availability of ancillary information for the wells to be sampled, including well construction data and contact information for the current well owners. The final selection included wells used for domestic supply, irrigation, public supply, recreational facilities, commercial establishments, industrial cooling, and livestock watering (fig. 2).

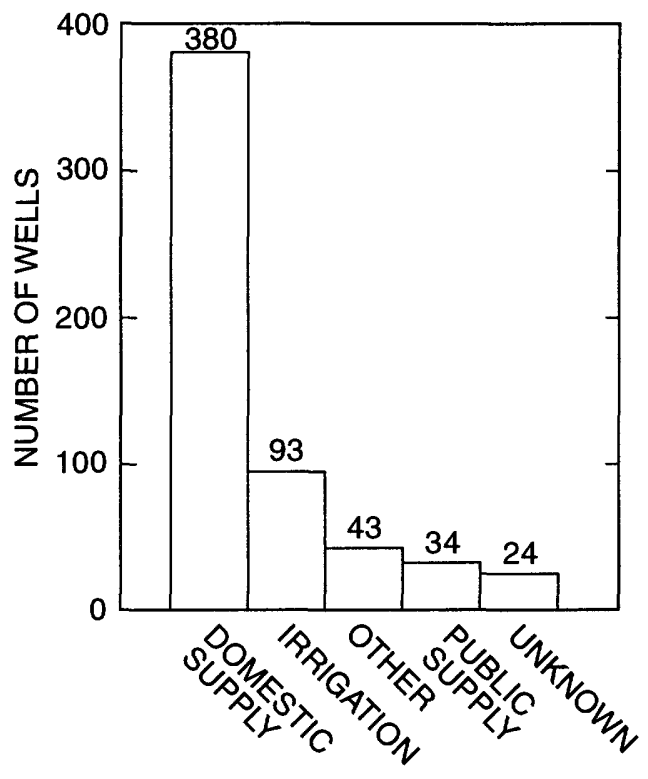

Figure 2. Numbers of wells sampled in different water use categories. The "Other" category includes wells used for recreational facilities, commercial establishments, industrial cooling, and livestock watering.

\section{Sampling Regions}

The Columbia Basin GWMA is organized into five Ground Water Advisory Committees (GWAC), each chartered by the GWMA Executive Board to create recommendations and submit plans to address nitrate issues in their particular areas of interest. The five GWACs include an Irrigated and Dryland Agriculture GWAC; an Urban and Rural Residential GWAC; a Sprayfields and Wastewater Management GWAC; a Dairy, Feedlot, and Cattlemen GWAC; and an Environment and Recreation GWAC. Under the presumption that agricultural practices are the major influence over nitrate concentrations in ground water, the Irrigated and Dryland Agriculture GWAC designated 17 regions of the GWMA as Community Producer Groups (CPG). These CPGs were used as the basis for the mass sampling event in fall 1998.

According to John Larson, Irrigated and Dryland Agriculture GWAC (written commun., August 1998), the CPGs are areas defined geographically by soil types, irrigation systems, natural boundaries (water bodies, mountains), and communities. The logical population base or geographic location within each county names the CPG area. Each CPG area is represented by one voting member on the GWMA's Irrigated 
and Dryland Agriculture GWAC. Grant County has nine CPGs because of the diverse topography of the county, although the Quincy and Ephrata CPGs were merged for the purposes of site selection and data summary, as were the Royal East and Sand Hollow CPGs (table 1). Adams County is divided into three CPGs, but is divided into five areas for the water sampling because of the need for more wells to be sampled to help fill in gaps in Adams County. Franklin County is divided into five different CPGs. Figure 3 shows the boundaries of the 17 sampling regions used to select wells for sampling and to summarize the nitrate data for this report.

\section{Categorizing Wells by Depth}

Many ground-water studies have shown that nitrate concentrations are generally lower at greater depths below the land surface (Alley, 1993). This relation appears to be strong in existing data from the Columbia Basin (Ryker and Jones, 1995). Well depth was the primary criterion used in this study to represent depth below land surface. Well depth is conceptually simple and more than 98 percent of the sampled wells had well depth information (table 2). Other variables, such as the open interval of the well or the primary hydrogeologic unit that the well takes water from, were considered for representation of depth below land surface. However, these variables were not used in this study because only about 70 percent of the wells have hydrogeologic unit information or open-interval information. In addition to the incomplete information on these variables, the interpretation of such information can be complex. For example, of the sampled wells with open-interval information, nearly two-thirds have an open interval of at least 50 feet and the average open-interval length was nearly 200 feet. With such long open intervals, wells will draw water from many different depths and selection of a single depth for analysis is not possible. Using hydrogeologic units to represent depth below land surface is also complex. Some of the units are thick (in excess of 1,000 feet) and almost a quarter of the sampled wells with hydrogeologic unit information potentially draw water from more than one unit. Given these difficulties, the choice to use well depth was the best alternative.

Within each sampling region, existing data were examined graphically by plotting the nitrate concentrations for each sampling region versus well depth.
Approximate depth breakpoints were selected (table 3) based on nitrate concentration variation over the range of well depths in the sampling region. These depth breakpoints are somewhat arbitrary and are intended to illustrate overall relations between well depth and nitrate concentration for groups of wells rather than to provide specific information on individual wells in specific hydrogeologic or land-use settings. It should be noted that the depth of the well is not the same as the depth to water nor is it necessarily the depth from which the sample is drawn. There are many local or small-scale complexities in the ground-water system that affect the concentration of nitrate in the water, so well depth alone should not be used to state that a well of any given depth is either high- or low-risk. The categories that are used are just a way of providing a more detailed summary for each sampling region, with a summary being provided for the total dataset as well as being broken down into smaller categories.

Based on the existing nitrate data, most sampling regions were divided into a shallow group of wells and a deep group of wells. In Pasco and Basin City sampling regions (fig. 3), high nitrate concentrations were present at greater depths in the ground-water system than in the other sampling regions, necessitating a middle depth group of wells. For each depth group within a sampling region, wells to be sampled were selected using areally random site-selection software (Scott, 1990) in a geographic information system.

Several factors can complicate the interpretation of the relation between well depth and nitrate concentration. One of the main factors controlling the amount of nitrate that will be transported to depth is the vertical component of ground-water flow. In regions where ground-water flow is mainly downward, nitrate will be carried deeper into the ground-water system. However, in areas where ground-water flow is upward, water from deeper geologic units containing lower nitrate concentrations may be transported into the overlying, shallower units. This can result in wells in areas of upward flow having lower nitrate concentrations than wells of the same depth in a region of downward flow. Additionally, many wells are open over a large depth interval. This can complicate the relation between nitrate and depth because a well considered to be in the deep well category could also be drawing water from the depths included in the shallow category. For wells in this dataset, it is generally safe to assume that the well is open at the well depth. 
Table 1. Descriptions and areas of sampling regions (modified from John Larson, written commun., August 1998, Columbia Basin GWMA web page www.gwma.org, 1999)

[CPG, Community Producer Group]

\begin{tabular}{|c|c|c|c|}
\hline \multirow{2}{*}{$\begin{array}{l}\text { Sampling region } \\
\text { Whole GWMA }\end{array}$} & \multirow[t]{2}{*}{ Description } & \multicolumn{2}{|c|}{$\begin{array}{l}\text { Area, in square miles } \\
\text { (square kilometers) }\end{array}$} \\
\hline & & 5,985 & $(15,501)$ \\
\hline Adams County & & 1,930 & $(4,998)$ \\
\hline Adams dryland & $\begin{array}{l}\text { Includes all dryland agriculture producers in Adams County. } \\
\text { Most dryland is located in the eastern portion of the county. }\end{array}$ & 400 & $(1,035)$ \\
\hline Esquatzel & Southern portion of Adams dryland CPG & 361 & (934) \\
\hline Range & Eastern portion of Adams dryland CPG & 384 & (996) \\
\hline Deep well irrigators & $\begin{array}{l}\text { Includes all deep well irrigators in Adams County. The majority } \\
\text { of the deep well irrigators are located in the central portion of } \\
\text { the county. Center pivot is the irrigation system. }\end{array}$ & 572 & $(1,483)$ \\
\hline Othello & $\begin{array}{l}\text { Includes producers in the East Columbia Basin Irrigation District } \\
\text { boundary. Surface and sprinkler irrigation are used in this area. }\end{array}$ & 212 & $(550)$ \\
\hline Franklin County & & 1,264 & $(3,273)$ \\
\hline Basin City & $\begin{array}{l}\text { Located in the northwest corner of the county. Sprinkler irrigation } \\
\text { is the primary irrigation system with some surface irrigation. }\end{array}$ & 227 & $(587)$ \\
\hline Connell & $\begin{array}{l}\text { On the northern border of the county. Surface and sprinkler irriga- } \\
\text { tion are present in the Connell area. }\end{array}$ & 234 & (605) \\
\hline East Franklin & $\begin{array}{l}\text { The deep well irrigated farmland along the Snake River and the } \\
\text { east of Pasco. Center Pivot irrigation over sandy soils. }\end{array}$ & 157 & (406) \\
\hline Franklin dryland & $\begin{array}{l}\text { The dryland producers to the east of the Columbia Basin Irriga- } \\
\text { tion Project. The area has very little irrigation, with producers } \\
\text { growing dryland crops such as small grains. }\end{array}$ & 425 & $(1,101)$ \\
\hline Pasco & $\begin{array}{l}\text { Includes the majority of southern Franklin County from the Columbia } \\
\text { River to Highway } 395 \text {. Sprinkler irrigated over sandy soils. }\end{array}$ & 222 & (574) \\
\hline Grant County & & 2,792 & $(7,230)$ \\
\hline Black Sands & $\begin{array}{l}\text { Located south of Ephrata near the Frenchman Hills. Center pivot } \\
\text { irrigated farming over sandy soil with a shallow water table. }\end{array}$ & 475 & $(1,230)$ \\
\hline Hartline & $\begin{array}{l}\text { Northern portion of Grant County. Mostly dryland farming with } \\
\text { some deep well irrigators. }\end{array}$ & 676 & $(1,751)$ \\
\hline Mattawa & $\begin{array}{l}\text { Located on the Wahluke Slope of the Saddle Mountains. Center } \\
\text { pivot irrigation on sandy soil. }\end{array}$ & $\dot{181}$ & (469) \\
\hline Moses Lake & $\begin{array}{l}\text { Located east of Moses Lake. Sandy soils intermixed with gravelly } \\
\text { soil. Sprinkler-irrigated with some surface-irrigation in this area. }\end{array}$ & 401 & $(1,038)$ \\
\hline Quincy-Ephrata & $\begin{array}{l}\text { Ephrata CPG is located around the cities of Ephrata and Soap Lake. } \\
\text { Sprinkler irrigated farming over gravely soil. Quincy CPG is located } \\
\text { along the Quincy slope toward Ephrata and south through George. } \\
\text { Predominantly surface irrigated farming still in this area. }\end{array}$ & 555 & $(1,437)$ \\
\hline Royal Slope & $\begin{array}{l}\text { Royal East CPG is on the east end of the Royal Slope. This area } \\
\text { has a mixture of surface and sprinkler irrigation. Sand Hollow } \\
\text { CPG is on the west end of the Royal Slope. Predominantly center } \\
\text { pivot irrigation with some surface-irrigation that drains into the } \\
\text { Sand Hollow Wasteway. }\end{array}$ & 418 & $(1,082)$ \\
\hline Warden & $\begin{array}{l}\text { Located southeast of the Lind Coulee Wasteway. Mix of sprin- } \\
\text { kler and surface irrigation with a low infiltration soil. }\end{array}$ & 86 & (223) \\
\hline
\end{tabular}




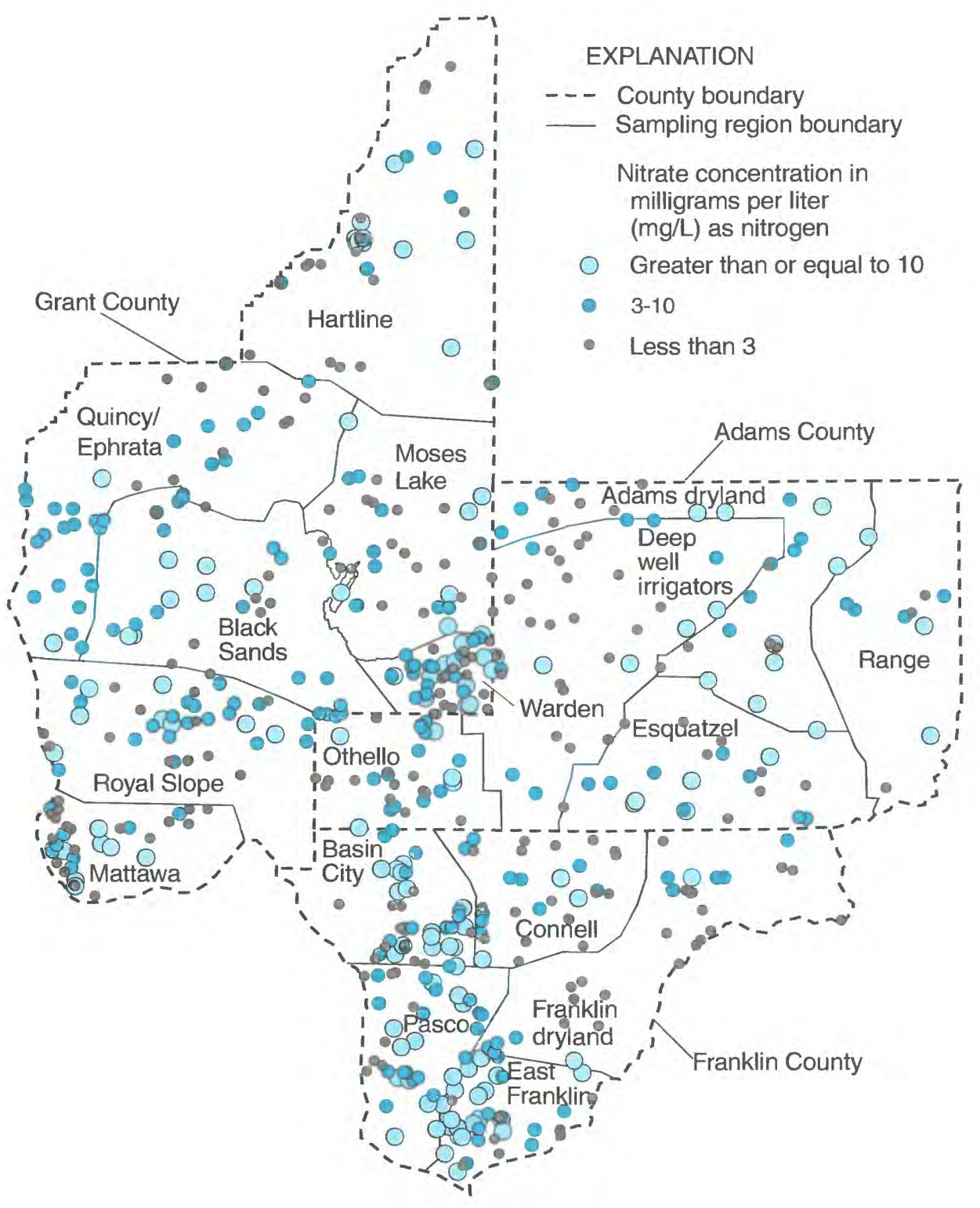

Figure 3. Locations and ranges of nitrate concentrations of the 574 wells sampled during fall 1998. 
Table 2. Existing information on wells sampled in the fall mass sampling and all wells in the GWMA study area from information stored in the National Water Information System

\begin{tabular}{|c|c|c|c|c|}
\hline & $\begin{array}{l}\text { Whole } \\
\text { GWMA }\end{array}$ & $\begin{array}{l}\text { Adams } \\
\text { County }\end{array}$ & $\begin{array}{l}\text { Franklin } \\
\text { County }\end{array}$ & $\begin{array}{l}\text { Grant } \\
\text { County }\end{array}$ \\
\hline \multicolumn{5}{|c|}{ Fall mass sampling wells } \\
\hline Number of wells & 574 & 133 & 180 & 261 \\
\hline Number of wells with well depth information ${ }^{1}$ & 565 & 131 & 173 & 261 \\
\hline Number of wells with hydrogeologic unit interpreted & 398 & 84 & 151 & 163 \\
\hline Number of wells with open interval information & 394 & 68 & 143 & 183 \\
\hline \multicolumn{5}{|c|}{ All wells in GWMA study area } \\
\hline Number of wells & 6,209 & 1,466 & 1,492 & 3,251 \\
\hline Number of wells with well depth information ${ }^{1}$ & 5,857 & 1,338 & 1,394 & 3,125 \\
\hline Number of wells with hydrogeologic unit interpreted & 3,777 & 998 & 1,049 & 1,730 \\
\hline Number of wells with open interval information & 2,309 & 475 & 829 & 1,005 \\
\hline
\end{tabular}

\footnotetext{
${ }^{1}$ In the USGS National Water Information System, well depth is not necessarily the same as hole depth. For example, a well might be drilled to 100 feet (hole depth), then filled so that the final well depth is only 90 feet.
}

Table 3. Depth categories used to select wells for sampling in each sampling region $[--$, not applicable $]$

\begin{tabular}{|c|c|c|c|}
\hline & $\begin{array}{l}\text { Depth of wells in } \\
\text { shallow category }\end{array}$ & $\begin{array}{l}\text { Depth of wells in } \\
\text { middle category }\end{array}$ & $\begin{array}{l}\text { Depth of wells in } \\
\text { deep category }\end{array}$ \\
\hline \multicolumn{4}{|l|}{ Adams County } \\
\hline Othello & Less than 200 feet & -- & 200 feet or greater \\
\hline Deep well irrigators & Less than 200 feet & -- & 200 feet or greater \\
\hline Adams dryland & Less than 200 feet & - & 200 feet or greater \\
\hline Esquatzel & Less than 200 feet & - & 200 feet or greater \\
\hline Range & Less than 200 feet & -- & 200 feet or greater \\
\hline \multicolumn{4}{|l|}{ Franklin County } \\
\hline Basin City & Less than 200 feet & 200 to 400 feet & 400 feet or greater \\
\hline Connell & Less than 200 feet & -- & 200 feet or greater \\
\hline Franklin dryland & Less than 200 feet & -- & 200 feet or greater \\
\hline Pasco & Less than 200 feet & 200 to 400 feet & 400 feet or greater \\
\hline East Franklin & Less than 200 feet & -- & 200 feet or greater \\
\hline \multicolumn{4}{|l|}{ Grant County } \\
\hline Hartline & Less than 150 feet & -- & 150 feet or greater \\
\hline Quincy/Ephrata & Less than 150 feet & -- & 150 feet or greater \\
\hline Moses Lake & Less than 200 feet & -- & 200 feet or greater \\
\hline Black Sands & Less than 200 feet & -- & 200 feet or greater \\
\hline Royal Slope & Less than 150 feet & -. & 150 feet or greater \\
\hline Warden & Less than 300 feet & -- & 300 feet or greater \\
\hline Mattawa & Less than 200 feet & -- & 200 feet or greater \\
\hline
\end{tabular}


An additional complicating factor in the relation between nitrate concentration and depth is the presence of irrigation canals in certain areas. Seepage of water with low nitrate concentrations from the irrigation canals may dilute the concentration of nitrate in the shallow ground water near the canal (Ebbert and others, 1995). Therefore, a shallow well in the vicinity of a canal (or another surface-water feature) may have a lower nitrate concentration than a nearby deeper well.

\section{Laboratory Analytical Methods}

The 574 samples collected during the fall 1998 GWMA mass sampling event were collected by personnel from the GWMA stakeholder agencies (primarily Conservation District and Health District employees) at existing well locations throughout Adams, Grant, and Franklin Counties. These samples were collected unfiltered at nearest tap to the well head after the well was purged for approximately $15 \mathrm{~min}$ utes. The samples were preserved with sulfuric acid and chilled, held for 1 to 7 days after sample collection, and then shipped to the Washington Department of Ecology Manchester Laboratory in Manchester, Washington, for analysis. The laboratory used EPA method 353.2, a cadmium-reduction analytical method (U.S. Environmental Protection Agency, 1993) that reports results including both nitrite and nitrate (nitrite-plusnitrate), in milligrams per liter (mg/L) as nitrogen. A previous study of nitrate in parts of the Columbia Basin (Ebbert and others, 1995) reported that nitrite concentrations in the study area are generally below the analytical reporting limit of $0.01 \mathrm{mg} / \mathrm{L}$ as nitrogen. Therefore, throughout this report, the results of these samples are assumed to represent nitrate exclusively and are referred to only as nitrate.

During the fall 1998 GWMA mass sampling event, replicate samples of both well water and reference solution were sent to the USGS National WaterQuality Laboratory (NWQL) and a contract laboratory used by the Franklin Conservation District's nitrate monitoring program between 1988 and 1998 as well as to the WDOE Manchester Laboratory to verify comparability of sampling results (Appendix A). Replicate samples are collected in sequential order and can be used to assess the variability of the laboratory analysis. Verifying the comparability of sampling results is important because it allows for the inclusion of previously collected data, thereby generating a larger dataset for analysis.
Eight samples of reference solution were collected in replicate and sent to each laboratory in a blind interlaboratory method comparison. For this comparison, the USGS NWQL facilities in Denver, Colo., and Ocala, Fla., provided reference solutions at a variety of concentrations. Additionally, 28 replicate well-water samples were sent to both the Manchester and contract laboratories, and 9 replicate well-water samples were sent to both the NWQL and Manchester laboratories.

The samples sent to the NWQL were analyzed using a cadmium reduction method (Fishman, 1993) similar to the Manchester Laboratory method, while the contract laboratory used an ion-selective electrode analytical method (Clesceri and others, 1998). The samples that were sent to the Manchester Laboratory and the contract laboratory were preserved with sulfuric acid, while the NWQL samples were not preserved. Further information regarding the effects of preservation on samples can be found in Patton and Gilroy (1999).

Nitrate results for the unpreserved USGS NWQL samples and the preserved WDOE Manchester Laboratory samples proved nearly identical (Appendix A). The difference in preservation between the two datasets does not pose a problem. The original comparison of the reference solution replicates revealed that the Manchester Laboratory was reporting concentrations twice as high as the NWQL. A review by the Manchester Laboratory determined that this discrepancy was the result of misreported dilution factors (Jim Ross, Manchester Laboratory, written commun., July 22,1999 ). A review of the entire dataset determined that the discrepancy was isolated to a small number of samples and was easily correctable.

Nitrate concentrations reported by the contract laboratory differed markedly from the concentrations reported by the two agency laboratories, likely due to the differing analytical methods. The ion-selective electrode results from the contract laboratory had higher variability than results from the other laboratories. The contract laboratory reported nitrate concentrations that were sometimes higher and sometimes lower, by varying degrees, than the concentrations reported by the other laboratories. Overall, as the nitrate concentrations of the reference solutions increased, the nitrate concentrations reported by the contract laboratory appeared to be increasingly underreported, in comparison to the results of the other laboratories. 
Based on these analytical method differences and quality-control results, no existing Franklin Conservation District nitrate data were included in this report. Inclusion of data produced by different analytical methods could potentially bias a baseline of current nitrate concentrations and any subsequent trend analysis. In planning future nitrate sampling, these laboratory analytical method differences should be minimized. Additionally, any future sampling should be conducted in autumn so that the effects of seasonality will be minimized, thereby making the future samples comparable to the current sampling.

\section{SUMMARY OF BASELINE NITRATE CONCENTRATIONS}

The fall 1998 nitrate concentrations appear to be consistent with previous studies in the GWMA area. However, previous data contained certain gaps: there were few existing nitrate data in Adams and northern Grant Counties. In addition, existing nitrate data in the GWMA were collected in a variety of seasons and analyzed using a variety of methods. The fall 1998 GWMA sampling thus provides the first large dataset collected with consistent methods at one time.

\section{Comparison of Concentrations Within the Ground Water Management Area}

Summary statistics as well as the relation between nitrate concentration and depth were examined for the 574 wells sampled throughout the 17 sampling regions within the three-county area (fig. 3). These summary statistics were computed for different ranges of well depths in each sampling region. Nitrate concentrations exceeded the U.S. Environmental
Protection Agency MCL of $10 \mathrm{mg} / \mathrm{L}$ of nitrate in drinking water in approximately 23 percent of the wells sampled (table 4). The highest rate was in Franklin County, with 30 percent of the samples exceeding the MCL, while in both Adams and Grant Counties approximately 20 percent of the samples exceeded the MCL. Across the whole GWMA area, approximately 37 percent of sampled wells had nitrate concentrations between 3 and $10 \mathrm{mg} / \mathrm{L}$, constituting a large group of wells with nitrate concentrations above naturally occurring levels but not exceeding the MCL (table 5). In most sampling regions, elevated concentrations of nitrate were found most frequently among shallow wells (fig. 4).

In this report, a nitrate concentration of $3 \mathrm{mg} / \mathrm{L}$ or higher is considered an elevated concentration indicating the likely presence of anthropogenic (humancaused) factors that may contribute to nitrate in ground water (Madison and Brunett, 1985). A national study (U.S. Geological Survey, 1999) has recently estimated that naturally occurring nitrate in shallow ground water of relatively undeveloped areas is typically below $2.0 \mathrm{mg} / \mathrm{L}$, based on data from wells less than 100 feet deep. Within the Columbia Basin, a 1980's study in Franklin County (Ebbert and others, 1995) found negligible amounts of natural nitrate. Other concentrations have been used to represent natural nitrate concentrations in Washington State down to as low as $1 \mathrm{mg} / \mathrm{L}$ (Washington Toxics Coalition, 1994). The use of $3 \mathrm{mg} / \mathrm{L}$ therefore may be considered a conservative estimate that is unlikely to overestimate the presence of elevated concentrations of nitrate.

Concentrations of nitrate equal to $10 \mathrm{mg} / \mathrm{L}$ or greater exceed the EPA MCL for nitrate in drinking water. The large number of Columbia Basin wells exceeding this criterion was one of the key factors in the formation of the GWMA (Washington State Interagency Ground Water Committee, 1996), and

Table 4. Percentage of samples exceeding the U.S. Environmental Protection Agency maximum contaminant level for nitrate for each county and category of well depths sampled

[mg/L, milligrams per liter; \%, percent; --, not applicable]

\begin{tabular}{lllll}
\hline & $\begin{array}{l}\text { Adams } \\
\text { County }\end{array}$ & $\begin{array}{l}\text { Franklin } \\
\text { County }\end{array}$ & $\begin{array}{l}\text { Grant } \\
\text { County }\end{array}$ & $\begin{array}{l}\text { Whole } \\
\text { GWMA }\end{array}$ \\
\hline Shallow wells & $31 \%$ & $35 \%$ & $23 \%$ & $28 \%$ \\
Middle wells & -- & $47 \%$ & - & $47 \%$ \\
Deep wells & $11 \%$ & $19 \%$ & $16 \%$ & $16 \%$ \\
All wells & $21 \%$ & $30 \%$ & $20 \%$ & $23 \%$ \\
\hline
\end{tabular}


Table 5. Summary of nitrate concentrations in the Columbia Basin GWMA area

[mg/L, milligrams per liter; \%, percent]

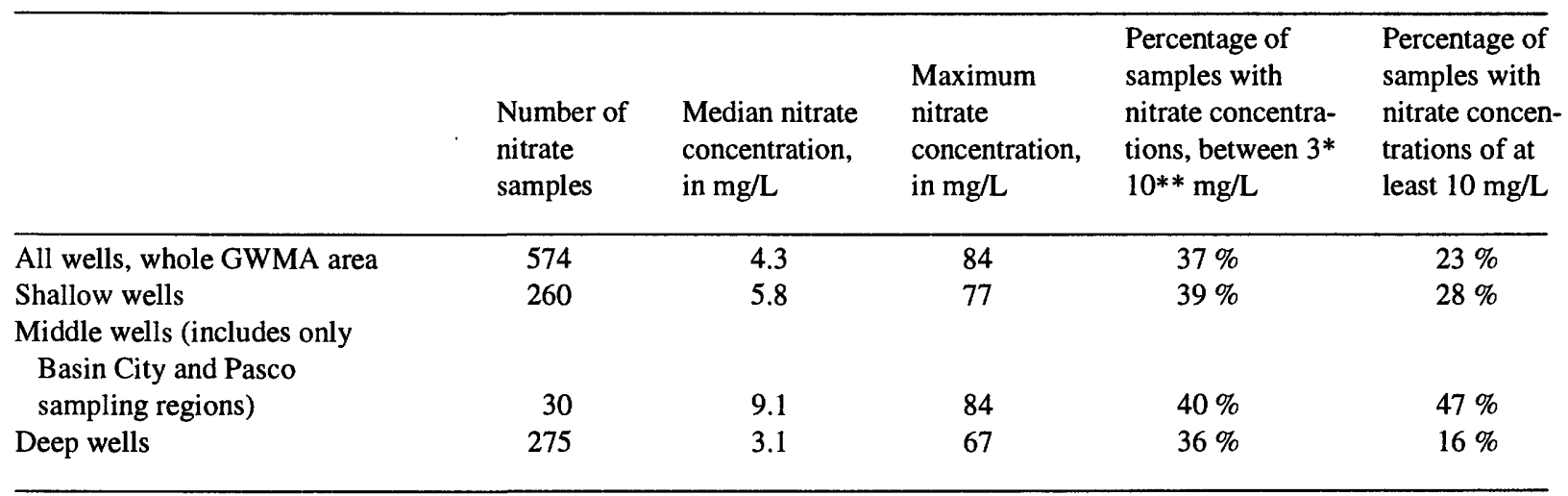

${ }^{*}$ Less than $3 \mathrm{mg} / \mathrm{L}$ could be considered naturally occurring nitrate (see p. 10 ).

**10 mg/L is the U.S. Environmental Protection Agency maximum contaminant level for nitrate in drinking water.

comparison of nitrate concentrations with the MCL will likely continue to be significant in future assessments of water quality in the Columbia Basin.

The maximum nitrate concentration detected in the GWMA was $84 \mathrm{mg} / \mathrm{L}$, which occurred in the middle depth category of wells (table 5). The shallow and deep well categories had maximum nitrate concentrations of $77 \mathrm{mg} / \mathrm{L}$ and $67 \mathrm{mg} / \mathrm{L}$, respectively. The maximum detected concentration of nitrate is included in this report to facilitate comparisons with future sampling results. Given the high seasonal and spatial variability of nitrate concentrations in ground water, a single high concentration in one sampling region or depth category should not be generalized to imply widespread high concentrations in that region. A single high concentration of nitrate may reflect smallscale, individual well-construction and land-use issues, whereas a measure of central tendency such as the median is a more reliable indicator of nitrate concentrations for a geographic region or depth zone. The maximum and median concentrations of nitrate during the fall 1998 sampling are illustrative of the difference. Adams, Franklin, and Grant Counties had maximum nitrate concentrations of 77,84 , and $56 \mathrm{mg} / \mathrm{L}$, respectively; these figures appear to indicate that nitrate concentrations in Adams County are higher than those of Grant County. Yet, Adams and Grant Counties have similar median nitrate concentrations $(3.7 \mathrm{mg} / \mathrm{L}$ and $4.0 \mathrm{mg} / \mathrm{L}$, respectively), and Grant County may actually have a more widespread pattern of high concentrations and in both shallow and deep wells, as tables 13 and 21 and figures $14 \mathrm{a}-\mathrm{b}$ and $23 \mathrm{a}-\mathrm{b}$ show.
More than 50 percent of the sampled wells had nitrate concentrations exceeding $4 \mathrm{mg} / \mathrm{L}$ as the boxplot in figure 5a indicates, while a little less than 25 percent of the wells exceeded the MCL of $10 \mathrm{mg} / \mathrm{L}$. The shallow wells group had a higher median concentration and exhibited greater variability in concentrations, as shown by the longer box, than the deep wells. The "Middle wells" group had the greatest variability and the highest median concentration with nearly 50 percent of the samples exceeding the MCL. However, the "Middle wells" group represents only 30 Basin City and Pasco wells between 200 and 400 feet deep, an unusually high-nitrate group of wells (see the individual boxplots for these sampling regions, figs. $8 \mathrm{a}$ and $12 a)$. It should be noted that the number of samples in the all-wells category does not equal the sum of the shallow, middle, and deep well categories. This occurs because a few wells are missing depth data and could not be assigned to a depth category.

In addition to boxplots, plots of nitrate concentration versus well depth are also presented. In much of the GWMA, the general relation between nitrate concentration and well depth is that nitrate concentrations generally decrease with depth (fig. 5b). The variability of nitrate concentrations is much greater among shallow wells. At a depth of approximately $100 \mathrm{feet}$, 10 percent of the sampled wells had nitrate concentrations above $21 \mathrm{mg} / \mathrm{L}$, while at a depth of approximately 750 feet, the top 10 percent of concentrations had a nitrate concentration above $14 \mathrm{mg} / \mathrm{L}$.

The curves overlaid on the graphs represent estimated moving percentiles calculated using the LOWESS (locally-weighted scatterplot smoothing) 


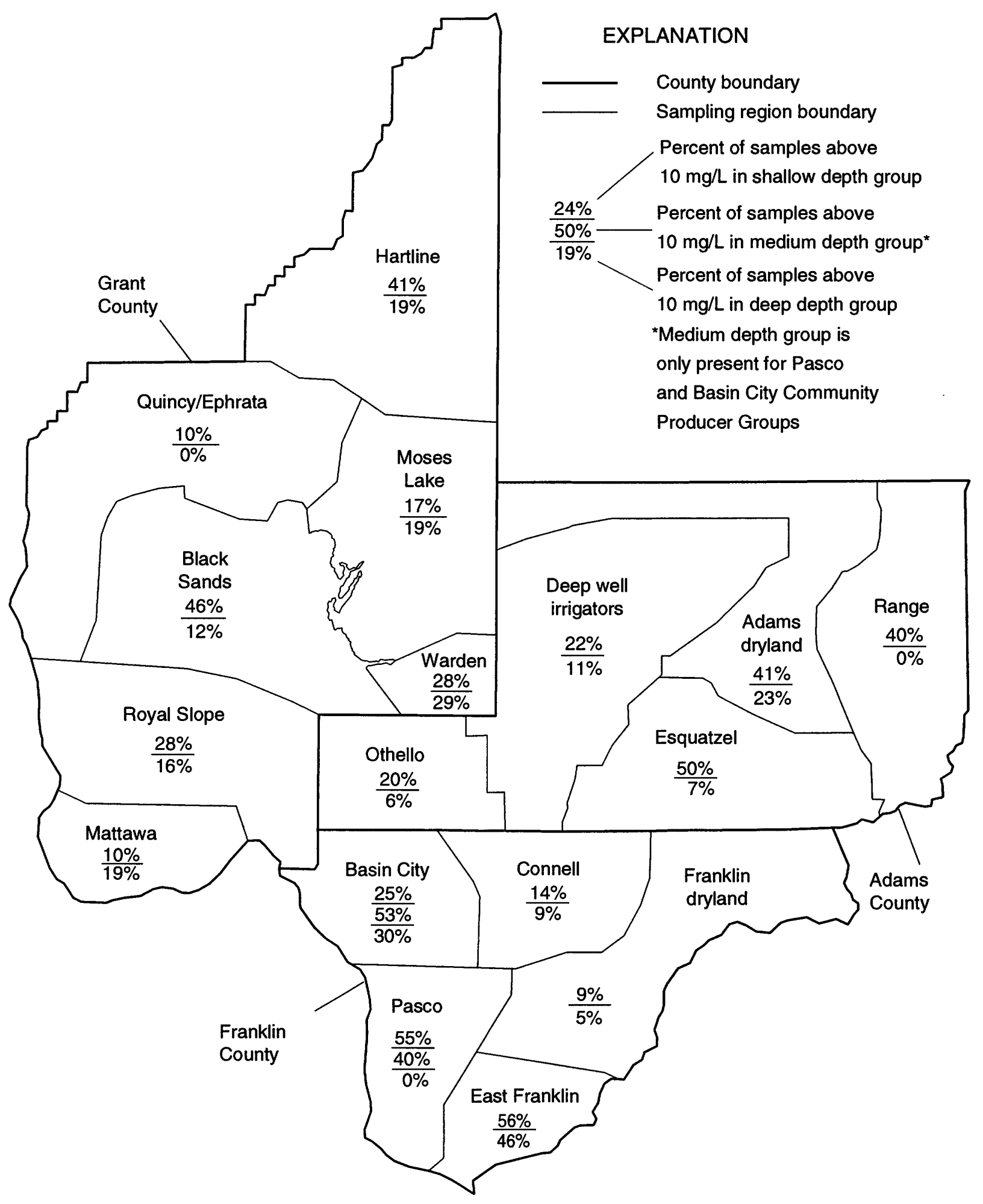

Figure 4. The percentage of samples exceeding the U.S. Environmental Protection Agency maximum contaminant level (MCL) for nitrate in drinking water (10 milligrams per liter of nitrate as nitrogen) for each sampling region and the category of well depths sampled. 


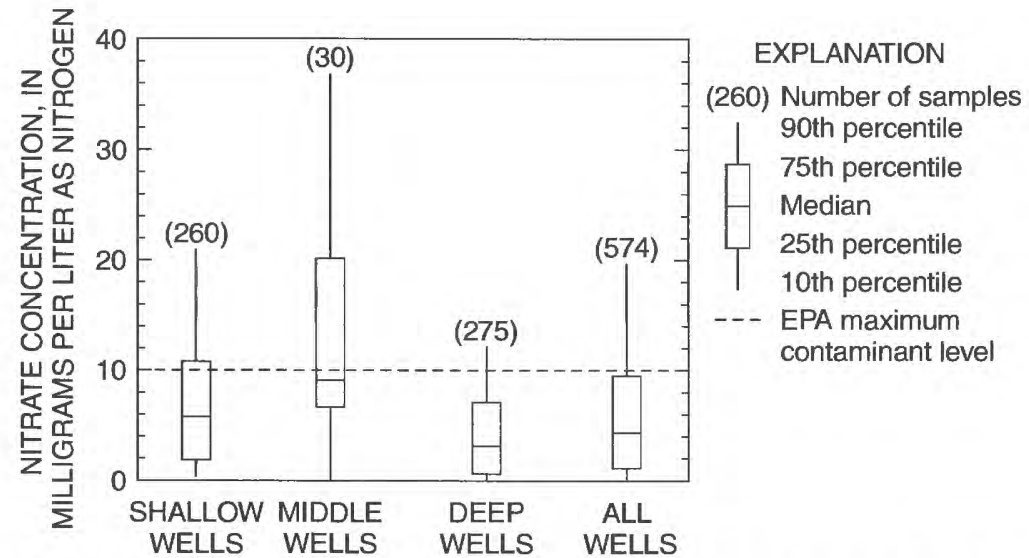

Figure 5a. The distribution of nitrate concentrations for groups of wells sampled across the Ground Water Management Area (categorized by ranges of well depths; see table 3 ). Note that only the Basin City and Pasco sampling regions have "middle" depth categories of wells, so the "Middle wells" boxplot is based on only 30 wells and represents an unusually high-nitrate group of wells for that range of depths.

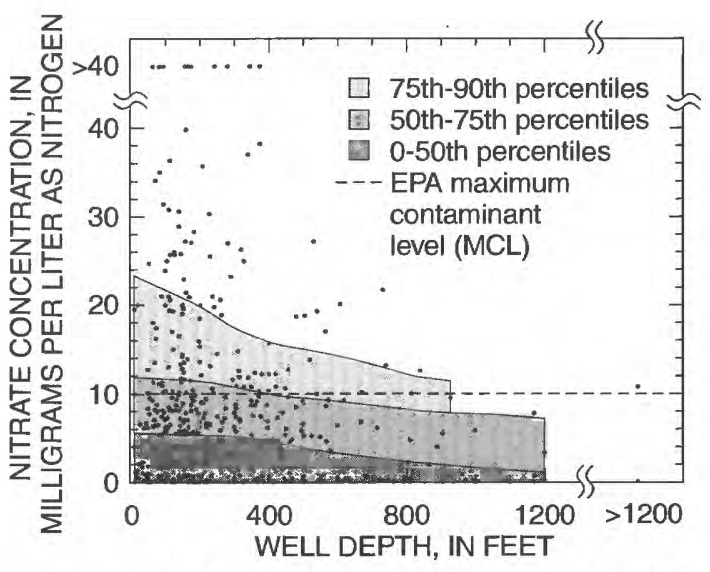

Figure 5b. Concentrations of nitrate in sampled wells, with lines representing moving 50th, 75th, and 90 th percentiles of concentration for varying depths (estimated using the LOWESS method; see page 13). method (modified from Helsel and Hirsch, 1992). The lowest line on the plot is an estimated moving median (50th percentile) such that at any particular depth, half the wells sampled had nitrate concentrations less than the median line, while half the wells sampled had concentrations greater than the median. For example, based on figure $5 \mathrm{~b}$ one could say that among wells close to 100 feet deep that were sampled in the GWMA, approximately 50 percent had nitrate concentrations below $6 \mathrm{mg} / \mathrm{L}$, and about 75 percent had a nitrate concentration below $12 \mathrm{mg} / \mathrm{L}$.

Note that these moving percentiles require some interpolation to draw the lines, as it is unlikely that the GWMA dataset includes a high number of wells precisely 100 feet deep. For this reason, and because these LOWESS curves are computed based on a moving cross section of the entire dataset for each sampling region, the curves will not always correspond exactly to the boxplots, which are computed for specific portions of the dataset. The strength of these LOWESS lines as a summary tool is that they simply follow the percentiles of the concentration data rather than predict a predetermined shape in the data (as do statistical modeling techniques such as linear regression). The 90th percentile line is only presented for the entire GWMA Summary and the three counties. Insufficient data points were present in the individual sampling regions to compute the 90 th percentile line.
Comparison of the median concentrations of all the sampling region categories reveals that it is generally the shallow well categories that fall at the top of the list (table 6). Shallow wells in the Esquatzel sampling region had the highest median nitrate concentration of all the sampling regions. However, this high number may be artificially inflated due to the low number of samples taken in the sampling region. The median nitrate concentration in shallow wells in Esquatzel, East Franklin, and Pasco sampling regions, as well as the 200- to 400-foot depth group in the Basin City sampling region, exceeded the EPA MCL of $10 \mathrm{mg} / \mathrm{L}$. The median concentrations in the rest of the sampling regions span the full spectrum from just less than the MCL for shallow wells in the Black Sands region to $0.3 \mathrm{mg} / \mathrm{L}$ in the deep wells of the Deep well irrigator sampling region of Adams County.

This report uses the median (50th percentile) as the primary statistic representing the center of the distribution of nitrate concentrations rather than a mean (average). While the mean is easily influenced by extreme values (such as a single high concentration of nitrate in a dataset), the median is a more resistant measure that is frequently used in reporting water-quality data. Use of the median is especially indicated for datasets with high variability and skewed distributions, as is often the case with nitrate concentrations in ground water. 
Table 6. Median concentrations of nitrate found in each sampling region, ranked in descending order of concentration. Where a sampling region/depth category had fewer than 10 samples, the rank is shown in parentheses [mg/L, milligrams per liter; $\mathrm{ft}$, feet]

\begin{tabular}{|c|c|c|c|}
\hline Rank & Sampling region, county, and depth of wells & $\begin{array}{l}\text { Number of } \\
\text { nitrate samples }\end{array}$ & $\begin{array}{l}\text { Median nitrate } \\
\text { concentration, in } \mathrm{mg} / \mathrm{L}\end{array}$ \\
\hline (1) & Esquatzel, Adams, less than $200 \mathrm{ft}$ deep & 8 & 14 \\
\hline 2 & East Franklin, Franklin, less than $200 \mathrm{ft}$ deep & 16 & 13 \\
\hline 3 & Basin City, Franklin, 200 to $400 \mathrm{ft}$ deep & 15 & 13 \\
\hline 4 & Pasco, Franklin, less than $200 \mathrm{ft}$ deep & 11 & 10 \\
\hline 5 & Black Sands, Grant, less than $200 \mathrm{ft}$ deep & 11 & 9.8 \\
\hline 6 & Pasco, Franklin, 200 to $400 \mathrm{ft}$ deep & 15 & 8.7 \\
\hline 7 & Basin City, Franklin, at least $400 \mathrm{ft}$ deep & 10 & 7.8 \\
\hline 8 & East Franklin, Franklin, at least $200 \mathrm{ft}$ deep & 22 & 7.4 \\
\hline 9 & Othello, Adams, less than $200 \mathrm{ft}$ deep & 20 & 6.4 \\
\hline 10 & Hartline, Grant, less than $150 \mathrm{ft}$ deep & 17 & 6.3 \\
\hline 11 & Royal Slope, Grant, less than $150 \mathrm{ft}$ deep & 23 & 6.2 \\
\hline 12 & Adams dryland, Adams, less than $200 \mathrm{ft}$ deep & 17 & 5.9 \\
\hline 13 & Warden, Grant, less than $300 \mathrm{ft}$ deep & 25 & 5.8 \\
\hline 14 & Royal Slope, Grant, at least $150 \mathrm{ft}$ deep & 19 & 5.5 \\
\hline (15) & Connell, Franklin, less than $200 \mathrm{ft}$ deep & 7 & 5.5 \\
\hline 16 & Basin City, Franklin, less than $200 \mathrm{ft}$ deep & 12 & 5.2 \\
\hline 17 & Warden, Grant, at least $300 \mathrm{ft}$ deep & 17 & 4.9 \\
\hline 18 & Quincy/Ephrata, Grant, at least $150 \mathrm{ft}$ deep & 20 & 4.1 \\
\hline (19) & Range, Adams, less than $200 \mathrm{ft}$ deep & 5 & 4.1 \\
\hline 20 & Quincy/Ephrata, Grant, less than $150 \mathrm{ft}$ deep & 21 & 3.9 \\
\hline 21 & Moses Lake, Grant, less than $200 \mathrm{ft}$ deep & 18 & 3.8 \\
\hline 22 & Black Sands, Grant, at least $200 \mathrm{ft}$ deep & 17 & 3.6 \\
\hline 23 & Hartline, Grant, at least $150 \mathrm{ft}$ deep & 21 & 2.9 \\
\hline 24 & Adams dryland, Adams, at least $200 \mathrm{ft}$ deep & 13 & 2.9 \\
\hline 25 & Deep well irrigators, Adams, less than $200 \mathrm{ft}$ deep & 18 & 2.7 \\
\hline 26 & Othello, Adams, at least $200 \mathrm{ft}$ deep & 16 & 2.6 \\
\hline 27 & Moses Lake, Grant, at least $200 \mathrm{ft}$ deep & 16 & 2.3 \\
\hline (28) & Range, Adams, at least $200 \mathrm{ft}$ deep & 3 & 2.2 \\
\hline 29 & Mattawa, Grant, less than $200 \mathrm{ft}$ deep & 20 & 2.2 \\
\hline 30 & Pasco, Franklin, at least $400 \mathrm{ft}$ deep & 12 & 1.9 \\
\hline 31 & Mattawa, Grant, at least $200 \mathrm{ft}$ deep & 16 & 1.7 \\
\hline 32 & Franklin dryland, Franklin, less than $200 \mathrm{ft}$ deep & 11 & 1.5 \\
\hline 33 & Esquatzel, Adams, at least $200 \mathrm{ft}$ deep & 13 & 1.5 \\
\hline 34 & Connell, Franklin, at least $200 \mathrm{ft}$ deep & 23 & 1.4 \\
\hline 35 & Franklin dryland, Franklin, at least $200 \mathrm{ft}$ deep & 19 & 1.1 \\
\hline 36 & Deep well irrigators, Adams, at least $200 \mathrm{ft}$ deep & 18 & 0.3 \\
\hline
\end{tabular}

\section{Additional Considerations in Calculating Baseline Statistics}

The fall 1998 mass sampling event was designed to sample approximately 20 nitrate samples in each category (for example, nitrate samples from 20 wells less than 200 feet deep in the Moses Lake sampling region). In general, statistical confidence in the sampling results is high where 20 nitrate samples were obtained for a sampling region/depth category. For some categories, less than the targeted number of wells were sampled; in sampling region/depth categories with less than 15 samples, statistical confidence in the results is somewhat lower, while sampling region/depth categories with less than 10 samples may not be satisfactorily represented by the wells sampled and may require further study.

The nitrate result was reported as less than $0.01 \mathrm{mg} / \mathrm{L}$ for samples in which nitrate was not detected. Depending on the calculations to be performed, such values are traditionally handled in one of three ways: the non-detections are eliminated from the dataset; the non-detection values are treated as zero; or the non-detection values are treated as detections at some value between zero and the laboratory reporting limit. For the GWMA dataset, all non-detections were treated as detections at $0.01 \mathrm{mg} / \mathrm{L}$ (the laboratory reporting limit). This has no significant biasing effect on the statistical calculations because the summary statistics presented in this report are based on percentiles, which are insensitive to this kind of data handling. 
FRANKLIN COUNTY

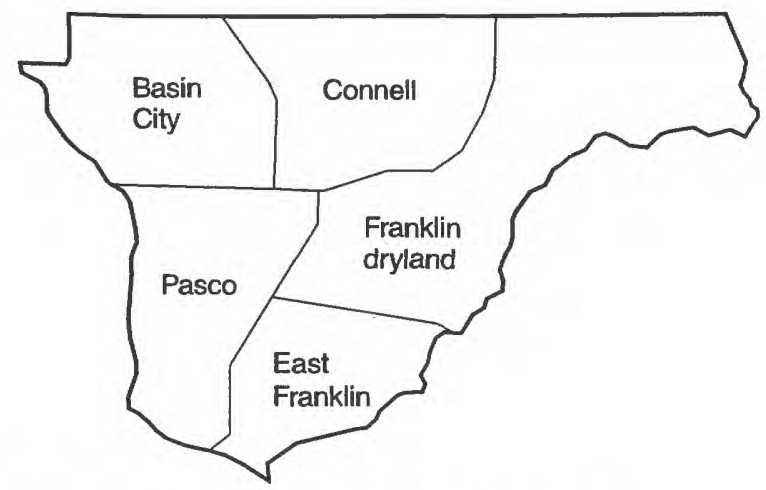

Figure 6. Sampling region boundaries in Franklin County.

The fall 1998 mass sampling for nitrate included 180 wells in Franklin County, distributed among the 5 sampling regions (fig. 6). All depth categories are well represented in much of Franklin County (table 7). See the "Additional
Considerations in Calculating Baseline Statistics" section for more information on targeted numbers of samples.

In Franklin County, high concentrations of nitrate are present in the middle depth ground-water system in the Basin City and Pasco sampling regions (fig. 7a). Also based on figure 7a, shallow wells in Franklin County appear to have a median concentration of nitrate that is approximately four times the median concentration of the "Deep wells" category. These relations are borne out by figure $7 \mathrm{~b}$, which shows that at a depth of 200 feet, 50 percent of the wells sampled had nitrate concentrations above $8 \mathrm{mg} / \mathrm{L}$, while at a depth of 700 feet only about 25 percent of the wells sampled had nitrate concentrations above $8 \mathrm{mg} / \mathrm{L}$.

In the 1980's the USGS conducted an investigation of ground-water resources in Franklin and Benton Counties (Drost and others, 1997; Ebbert and others, 1995). Since then, the Franklin Conservation District has conducted a nitrate monitoring program, under which approximately 55 wells have been sampled for nitrate once every 4 years. The Franklin Conservation District sampling results were excluded from this analysis because of differences in the laboratory analytical techniques (see page 10).

Table 7. Summary of nitrate concentrations in ground water, Franklin County

[mg/L, milligrams per liter; \%, percent]

\begin{tabular}{lccccc}
\hline & & $\begin{array}{l}\text { Median } \\
\text { nitrate } \\
\text { concen- } \\
\text { tration, } \\
\text { in } \mathrm{mg} / \mathrm{L}\end{array}$ & $\begin{array}{l}\text { Percentage of } \\
\text { samples with } \\
\text { nitrate concen- } \\
\text { trations between } \\
\text { samples }\end{array}$ & $\begin{array}{l}\text { and } 10 \mathrm{mg} / \mathrm{L} \\
\text { samples with } \\
\text { nitrate concen- } \\
\text { trations of at } \\
\text { least } 10 \mathrm{mg} / \mathrm{L}\end{array}$ & $\begin{array}{l}\text { Maximum } \\
\text { nitrate } \\
\text { concen- } \\
\text { tration, } \\
\text { in mg/L }\end{array}$ \\
\hline All wells & 180 & 5.9 & $34 \%$ & $30 \%$ & 84 \\
Shallow wells & 57 & 7.8 & $37 \%$ & $35 \%$ & 62 \\
Middle wells & 30 & 9.1 & $40 \%$ & $47 \%$ & 84 \\
Deep wells & 86 & 2.3 & $30 \%$ & $19 \%$ & 67 \\
\hline
\end{tabular}

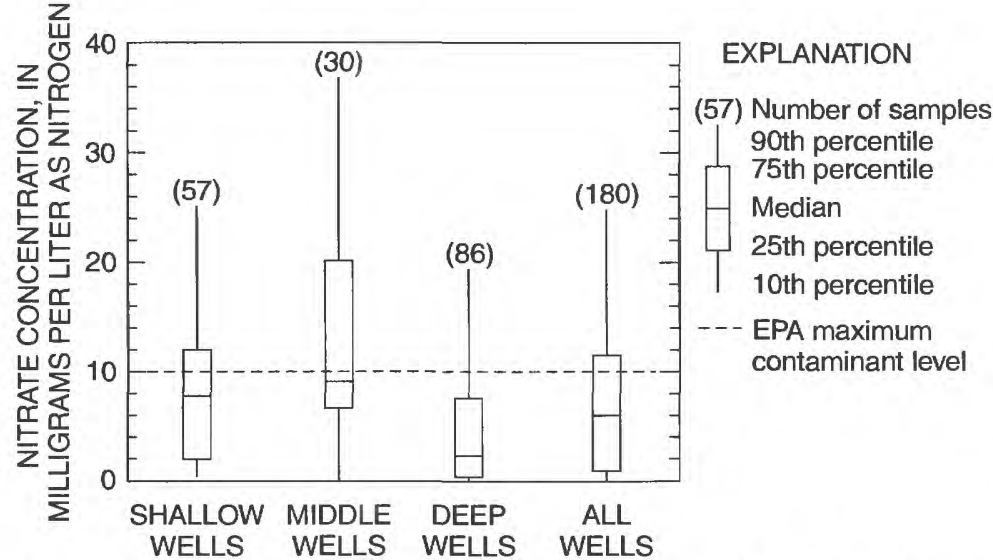

Figure 7a. The distribution of nitrate concentrations for groups of wells sampled in Franklin County (categorized by ranges of well depths; see table 3 and table 7). Note that the "Middle" depth boxplot represents only the Basin City and Pasco sampling regions.

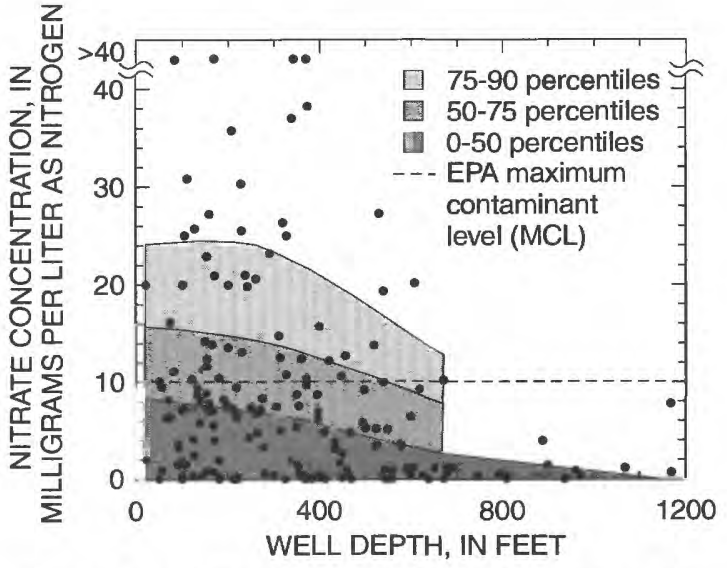

Figure $\mathbf{7 b}$. Concentrations of nitrate in sampled wells, with lines representing moving 50 th, 75 th, and 90 th percentiles of concentration for varying depths (estimated using the LOWESS method; see page 13). 


\section{Basin City}

The baseline dataset for the Basin City sampling region includes 40 samples obtained during the fall 1998 sampling event. Shallow and middle depth wells are well represented in this dataset, with 12 and 15 samples, respectively; wells over 400 feet deep are reasonably well represented, with 10 samples (table 8 ).

The "All wells" boxplot in figure 8a shows that of 40 wells sampled in the Basin City sampling region, 75 percent had nitrate concentrations below $18 \mathrm{mg} / \mathrm{L}$. Wells in the middle depth category had the highest median nitrate concentrations, while the median concentrations for the shallow and deep wells were lower. Shallow wells had the lowest median concentration of the three depth categories. Over 50 percent of the wells in the middle depth category exceeded the MCL, while only 25 percent of the shallow wells exceeded the MCL. There appears to be an increase in nitrate concentrations with increasing depth up to 300 feet below land surface (fig. 8 b). Below 300 feet, the trend with depth reverses, and nitrate concentrations decline with increasing depth.

Table 8. Summary of nitrate concentrations in ground water, Basin City, Franklin County [mg/L, milligrams per liter; $\mathrm{ft}$, feet; \%, percent]

\begin{tabular}{|c|c|c|c|c|c|}
\hline & $\begin{array}{l}\text { Number } \\
\text { of } \\
\text { samples }\end{array}$ & $\begin{array}{l}\text { Median } \\
\text { nitrate } \\
\text { concen- } \\
\text { tration, } \\
\text { in } \mathrm{mg} / \mathrm{L}\end{array}$ & $\begin{array}{l}\text { Percentage of } \\
\text { samples with } \\
\text { nitrate concen- } \\
\text { trations between } \\
3 \text { and } 10 \mathrm{mg} / \mathrm{L}\end{array}$ & $\begin{array}{l}\text { Percentage of } \\
\text { samples with } \\
\text { nitrate concen- } \\
\text { trations of at } \\
\text { least } 10 \mathrm{mg} / \mathrm{L}\end{array}$ & $\begin{array}{l}\text { Maximum } \\
\text { nitrate } \\
\text { concen- } \\
\text { tration, } \\
\text { in } \mathrm{mg} / \mathrm{L}\end{array}$ \\
\hline All wells & 40 & 7.6 & $33 \%$ & $40 \%$ & 84 \\
\hline Wells less than $200 \mathrm{ft}$ deep & 12 & 5.2 & $33 \%$ & $25 \%$ & 62 \\
\hline Wells 200 to $400 \mathrm{ft}$ deep & 15 & 13 & $33 \%$ & $53 \%$ & 84 \\
\hline Wells at least $400 \mathrm{ft}$ deep & 10 & 7.8 & $40 \%$ & $30 \%$ & 20 \\
\hline
\end{tabular}

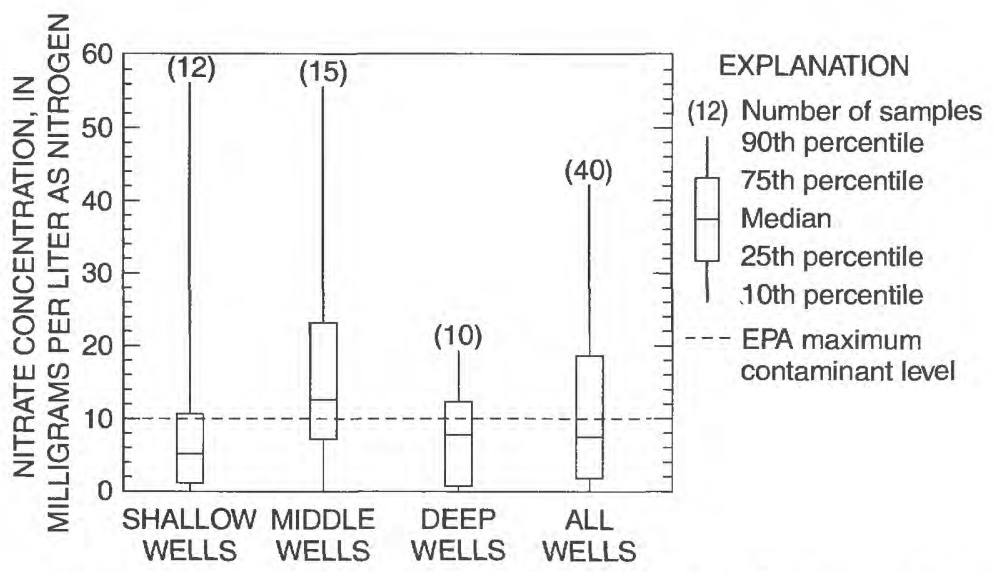

Figure 8a. The distribution of nitrate concentrations for groups of wells sampled in the Basin City sampling region (categorized by ranges of well depths; see table 3 and table 8 ).

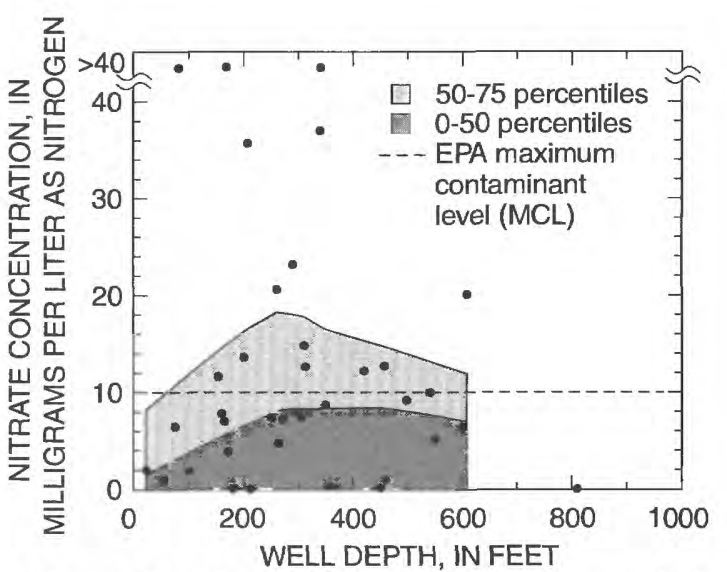

Figure $\mathbf{8 b}$. Concentrations of nitrate in sampled wells, with lines representing moving 50th and 75 th percentiles of concentration for varying depths (estimated using the LOWESS method; see page 13). 


\section{Connell}

The baseline dataset for the Connell sampling region includes 32 samples obtained during the fall 1998 sampling event. In the shallow category (wells less than 200 feet deep), only seven sample results were available, giving summary statistics for this category less certainty (table 9). The deep well category is well represented with 23 samples.

Fifty percent of the samples in the deep well category are found between 1 and $5 \mathrm{mg} / \mathrm{L}$ with over 90 percent of the samples having concentrations below the
MCL of $10 \mathrm{mg} / \mathrm{L}$ (fig. 9a). For the Connell sampling region as a whole, 13 percent of the wells exceeded the MCL. There appears to be a steady decline in nitrate concentration with increasing depth (fig. 9b). At a depth of 100 feet, 75 percent of the wells had a concentration below $8 \mathrm{mg} / \mathrm{L}$. Insufficient data were available in the shallow well category to generate a boxplot, so individual data points were plotted instead.

Table 9. Summary of nitrate concentrations in ground water, Connell, Franklin County [mg/L, milligrams per liter; $\mathrm{ft}$, feet; \%, percent]

\begin{tabular}{lcllll}
\hline & & $\begin{array}{l}\text { Median } \\
\text { nitrate } \\
\text { concen- } \\
\text { tration, } \\
\text { in } \mathrm{mg} / \mathrm{L}\end{array}$ & $\begin{array}{l}\text { Percentage of } \\
\text { samples with } \\
\text { nitrate concen- } \\
\text { trations between } \\
3 \text { and } 10 \mathrm{mg} / \mathrm{L}\end{array}$ & $\begin{array}{l}\text { Percentage of } \\
\text { samples with } \\
\text { nitrate concen- } \\
\text { trations of at } \\
\text { least 10 mg/L }\end{array}$ & $\begin{array}{l}\text { Maximum } \\
\text { nitrate } \\
\text { concen- } \\
\text { tration, } \\
\text { in mg/L }\end{array}$ \\
\hline $\begin{array}{l}\text { All wells } \\
\text { Wells less than 200 ft deep }\end{array}$ & 32 & 2.2 & $31 \%$ & $13 \%$ & 14 \\
Wells at least 200 ft deep & 23 & 5.5 & $43 \%$ & $14 \%$ & 10 \\
& 1.4 & $26 \%$ & $9 \%$ & 14 \\
\hline
\end{tabular}

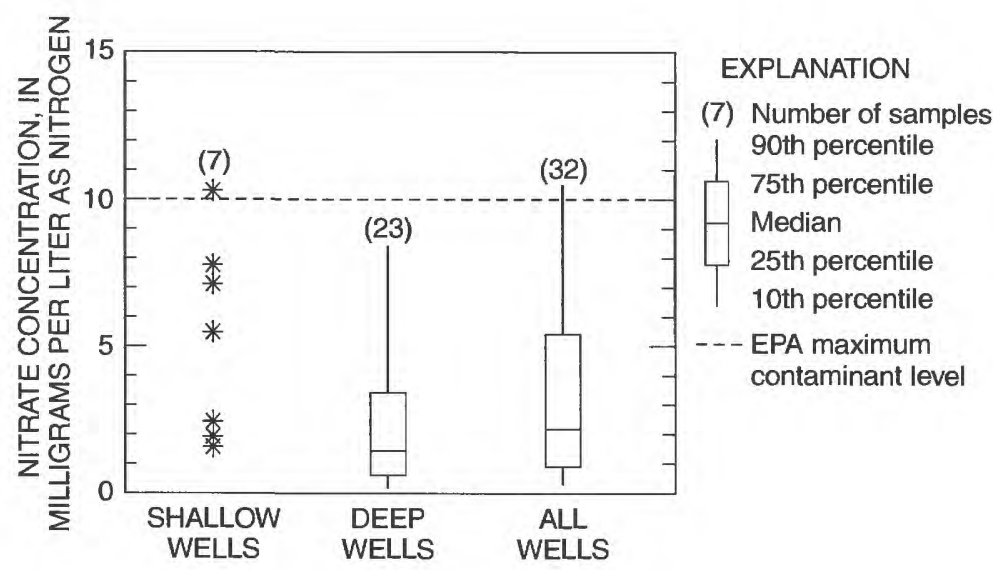

Figure 9a. The distribution of nitrate concentrations for groups of wells sampled in the Connell sampling region (categorized by ranges of well depths; see table 3 and table 9 ). Insufficient data were available for the shallow well category, so individual data points are plotted.

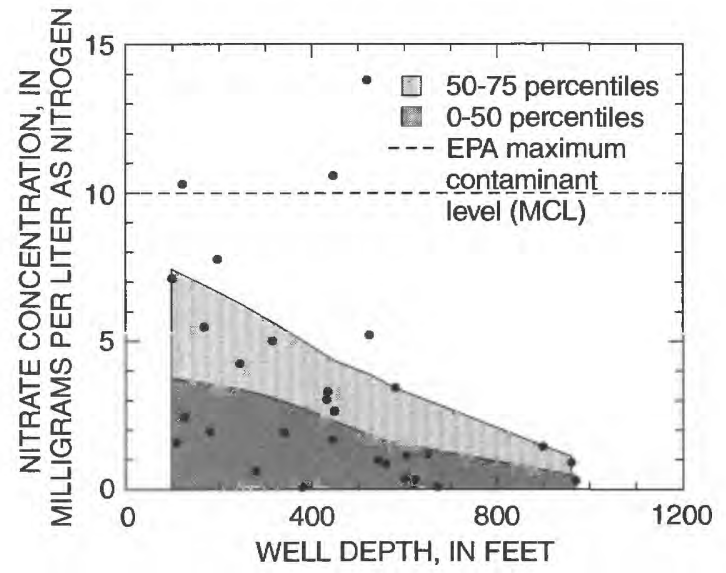

Figure 9b. Concentrations of nitrate in sampled wells, with lines representing moving 50th and 75th percentiles of concentration for varying depths (estimated using the LOWESS method; see page 13). 


\section{East Franklin}

The baseline dataset for the East Franklin sampling region includes 38 samples obtained during the fall 1998 sampling event. Both the shallow and the deep categories of wells are well represented, with 16 and 22 samples, respectively (table 10).

Shallow wells in the East Franklin sampling region show a distinctly higher median concentration of nitrate than the deeper wells (fig. 10a). However, the deeper wells exhibit more variability in their nitrate concentrations. In both depth categories, about 25 percent of the samples had concentrations above $22 \mathrm{mg} / \mathrm{L}$, but in the deep well category, the bottom 25 percent of the samples had concentrations less than $1 \mathrm{mg} / \mathrm{L}$. Over half of the shallow wells had nitrate concentrations exceeding the MCL of $10 \mathrm{mg} / \mathrm{L}$. In East Franklin, only one well less than 100 feet deep was sampled (fig. 10b).

Table 10. Summary of nitrate concentrations in ground water, East Franklin, Franklin County [mg/L, milligrams per liter; $\mathrm{ft}$, feet; \%, percent]

$\begin{array}{lllll} & \begin{array}{l}\text { Median } \\ \text { nitrate }\end{array} & \begin{array}{l}\text { Percentage of } \\ \text { samples with }\end{array} & \begin{array}{l}\text { Percentage of } \\ \text { samples with } \\ \text { concen- }\end{array} & \begin{array}{l}\text { Maximum } \\ \text { nitrate concen- } \\ \text { nitrate }\end{array} \\ \begin{array}{l}\text { nf } \\ \text { tration, }\end{array} & \begin{array}{l}\text { nations between } \\ \text { trations of at }\end{array} & \begin{array}{l}\text { concen- } \\ \text { tration, }\end{array} \\ \text { samples } & \text { in } \mathrm{mg} / \mathrm{L} & 3 \text { and } 10 \mathrm{mg} / \mathrm{L} & \text { least } 10 \mathrm{mg} / \mathrm{L} & \text { in } \mathrm{mg} / \mathrm{L}\end{array}$

\begin{tabular}{llrlll}
\hline All wells & 38 & 10.3 & $26 \%$ & $50 \%$ & 67 \\
Wells less than 200 ft deep & 16 & 13.2 & $31 \%$ & $56 \%$ & 31 \\
Wells at least 200 ft deep & 22 & 7.4 & $23 \%$ & $46 \%$ & 67 \\
\hline
\end{tabular}

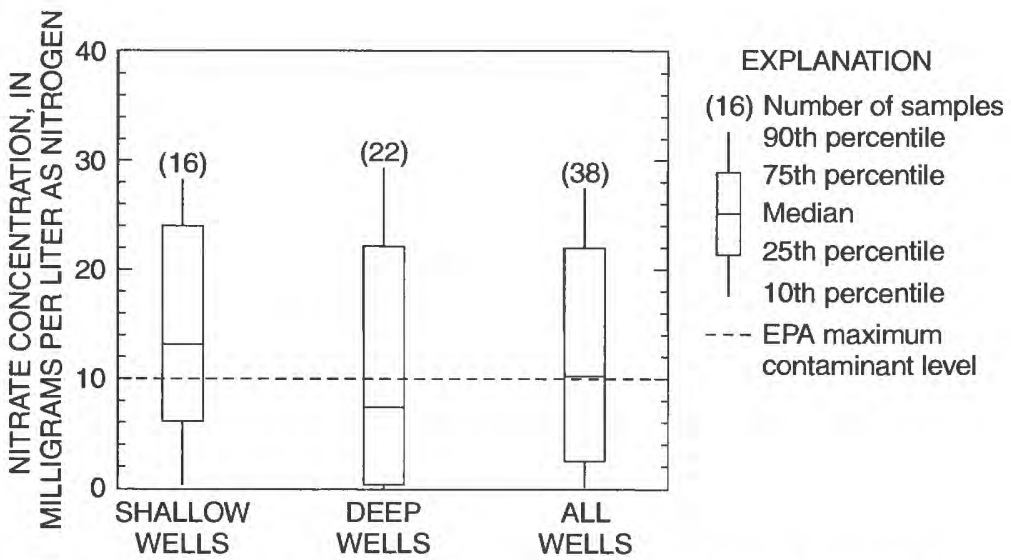

Figure 10a. The distribution of nitrate concentrations for groups of wells sampled in the East Franklin sampling region (categorized by ranges of well depths; see table 3 and table 10).

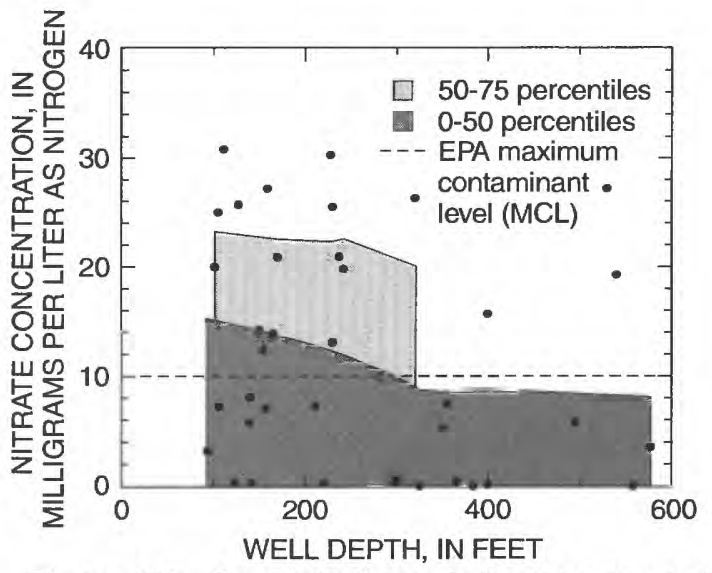

Figure 10b. Concentrations of nitrate in sampled wells, with lines representing moving 50th and 75th percentiles of concentration for varying depths (estimated using the LOWESS method; see page 13). 


\section{Franklin Dryland}

The baseline dataset for the Franklin dryland sampling region includes 31 samples obtained during the fall 1998 sampling event. Wells at least 200 feet deep are well represented, with 19 samples available; wells less than 200 feet deep, with 11 samples, are adequately represented (table 11 ).

Shallow and deep wells in the Franklin dryland sampling region show similar median and maximum concentrations of nitrate. Figures $11 \mathrm{a}$ and $11 \mathrm{~b}$ show that at all depths sampled, 50 percent of the wells fell below $1.2 \mathrm{mg} / \mathrm{L}$, and the maximum nitrate concentration was $10 \mathrm{mg} / \mathrm{L}$. The primary difference to note was in the distribution of concentrations within each group. Nitrate concentrations were far more variable among shallow wells: the range of nitrate concentrations between the 25th and 75th percentiles for the shallow wells was about $9 \mathrm{mg} / \mathrm{L}$, while the range for the deep wells was about $3.5 \mathrm{mg} / \mathrm{L}$.

Table 11. Summary of nitrate concentrations in ground water, Franklin dryland, Franklin County [mg/L, milligrams per liter; $\mathrm{ft}$, feet; $\%$, percent]

\begin{tabular}{llllll}
\hline & & $\begin{array}{l}\text { Median } \\
\text { nitrate } \\
\text { concen- } \\
\text { tration, } \\
\text { in } \mathrm{mg} / \mathrm{L}\end{array}$ & $\begin{array}{l}\text { Percentage of } \\
\text { samples with } \\
\text { nitrate concen- } \\
\text { trations between } \\
\text { samples }\end{array}$ & $\begin{array}{l}\text { Percentage of } \\
\text { samples with } \\
\text { nitrate concen- } \\
\text { trations of at } \\
\text { least } 10 \mathrm{mg} / \mathrm{L}\end{array}$ & $\begin{array}{l}\text { Maximum } \\
\text { nitrate } \\
\text { concen- } \\
\text { tration, } \\
\text { in mg/L }\end{array}$ \\
\hline $\begin{array}{l}\text { All wells } \\
\text { Wells less than 200 ft deep }\end{array}$ & 31 & 1.2 & $32 \%$ & $7 \%$ & 10 \\
Wells at least 200 ft deep & 19 & 1.5 & $36 \%$ & $9 \%$ & 10 \\
\end{tabular}

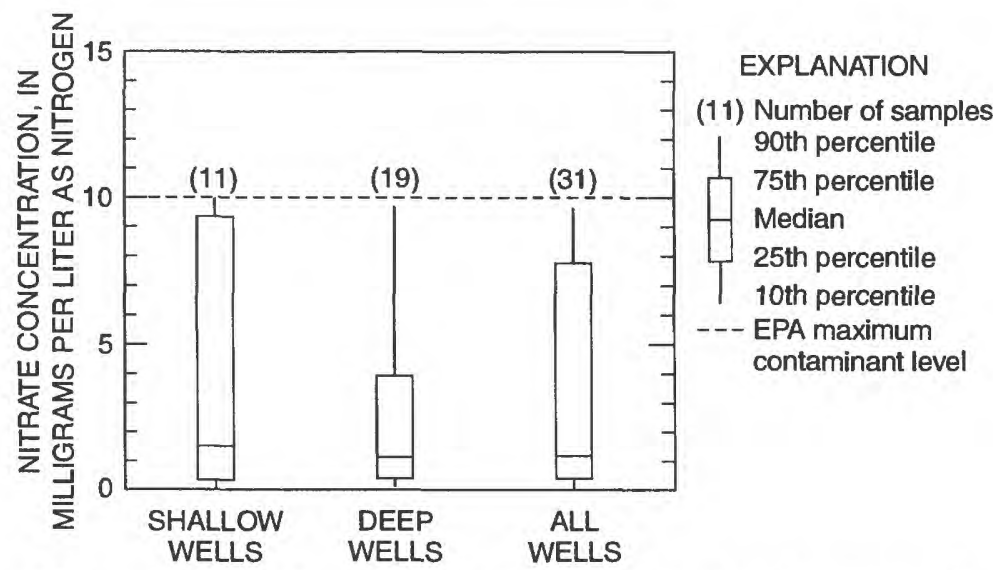

Figure 11a. The distribution of nitrate concentrations for groups of wells sampled in the Franklin dryland sampling region (categorized by ranges of well depths; see table 3 and table 11).

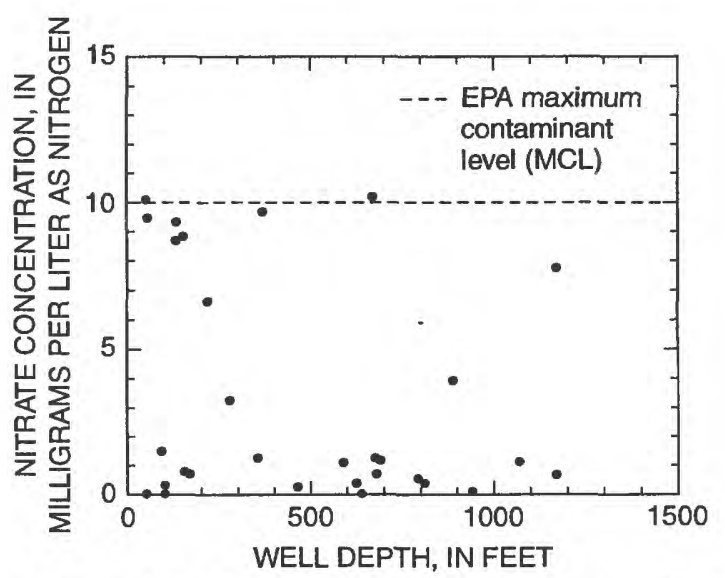

Figure 11b. Concentrations of nitrate in sampled wells. Insufficient data were available to draw LOWESS curves. 


\section{Pasco}

The baseline dataset for the Pasco sampling region includes 39 samples obtained during the fall 1998 sampling event. All depth categories sampled are adequately represented, particularly the middle group of wells with 15 samples (table 12).

Figure 12a and the "Maximum" column in table 11 appear to show higher concentrations of nitrate among middle depth wells in the Pasco sampling region. However, these maximum concentrations are isolated samples and not necessarily representative of an overall pattern. The boxplots in figure 12a suggest that the median concentrations, and the shape of the middle 50 percent of the data, are similar between shallow and middle depth categories of wells. However, the middle depth category of wells exhibits more variability at very high and very low concentrations, in the 10th- and 90th-percentile spikes. The shape of the LOWESS curves in figure $12 \mathrm{~b}$ indicates that nitrate concentrations decline overall with increasing well depth.

Table 12. Summary of nitrate concentrations in ground water, Pasco, Franklin County [mg/L, milligrams per liter; ft, feet; $\%$, percent]

\begin{tabular}{|c|c|c|c|c|}
\hline $\begin{array}{l}\text { Number } \\
\text { of } \\
\text { samples }\end{array}$ & $\begin{array}{l}\text { Median } \\
\text { nitrate } \\
\text { concen- } \\
\text { tration, } \\
\text { in } \mathrm{mg} / \mathrm{L}\end{array}$ & $\begin{array}{l}\text { Percentage of } \\
\text { samples with } \\
\text { nitrate concen- } \\
\text { trations between } \\
3 \text { and } 10 \mathrm{mg} / \mathrm{L}\end{array}$ & $\begin{array}{l}\text { Percentage of } \\
\text { samples with } \\
\text { nitrate concen- } \\
\text { trations of at } \\
\text { least } 10 \mathrm{mg} / \mathrm{L}\end{array}$ & $\begin{array}{l}\text { Maximum } \\
\text { nitrate } \\
\text { concen- } \\
\text { tration, } \\
\text { in } \mathrm{mg} / \mathrm{L}\end{array}$ \\
\hline
\end{tabular}

\begin{tabular}{lccccc}
\hline All wells & 39 & 6.9 & $46 \%$ & $33 \%$ & 38 \\
Wells less than 200 ft deep & 11 & 10 & $46 \%$ & $55 \%$ & 23 \\
Wells 200 to 400 ft deep & 15 & 8.7 & $47 \%$ & $40 \%$ & 38 \\
Wells at least 400 ft deep & 12 & 1.9 & $50 \%$ & $0 \%$ & 9.2
\end{tabular}

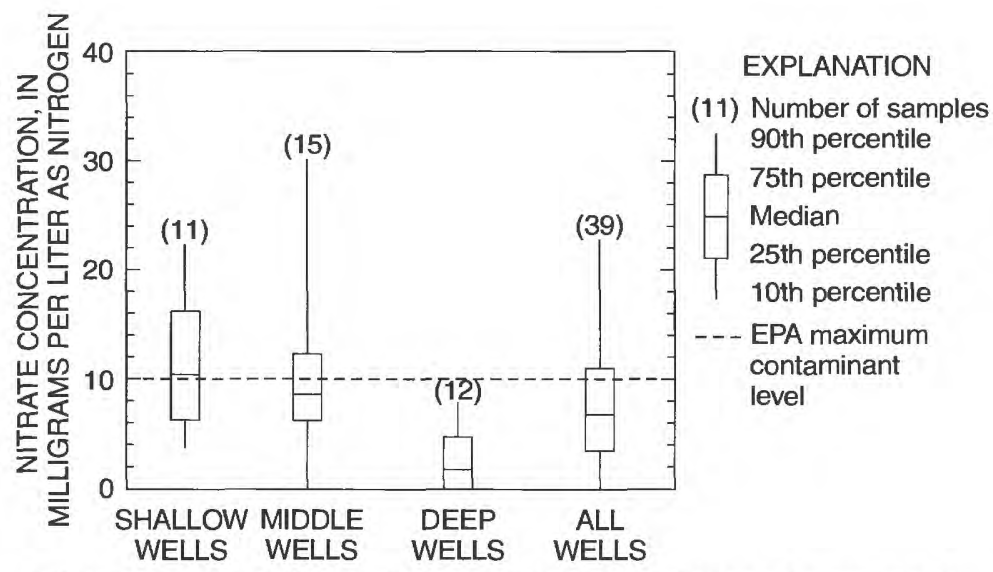

Figure 12a. The distribution of nitrate concentrations for groups of wells sampled in the Pasco sampling region (categorized by ranges of well depths; see table 3 and table 12).

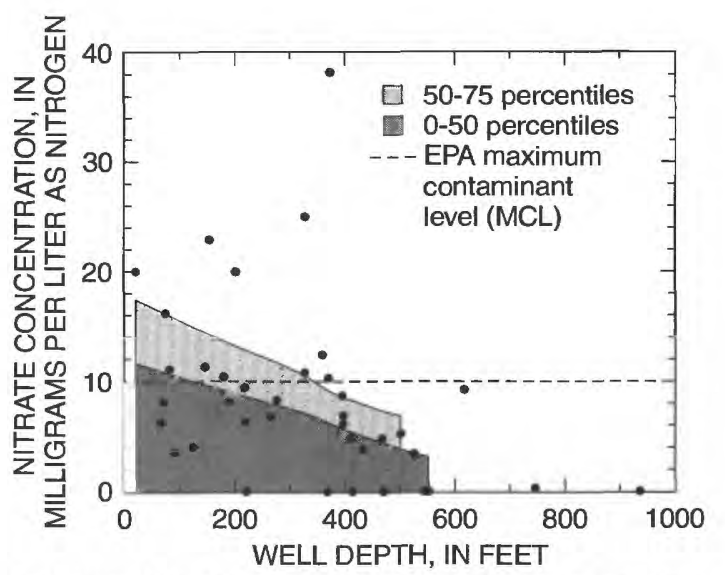

Figure 12b. Concentrations of nitrate in sampled wells, with lines representing moving 50th and 75th percentiles of concentration for varying depths (estimated using the LOWESS method; see page 13). 


\section{GRANT COUNTY}

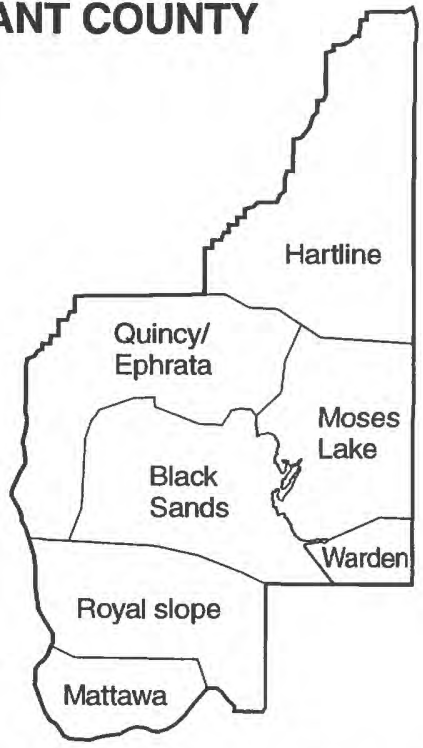

The fall 1998 mass sampling for nitrate included 261 wells in Grant County, distributed among the 7 sampling regions (fig. 13).

While the median concentrations in table 13 and the boxplots in figure 14a show similar distributions of nitrate in approximately half the wells in each category, high concentrations of nitrate are visible among shallow wells in figure $14 \mathrm{~b}$. The primary difference between depth categories appears to be the greater spread of concentrations among shallow wells.

Figure 13. Sampling region boundaries in Grant County.

Table 13. Summary of nitrate concentrations in ground water, Grant County [mg/L, milligrams per liter; \%, percent]

\begin{tabular}{|c|c|c|c|c|}
\hline $\begin{array}{l}\text { Number } \\
\text { of } \\
\text { samples }\end{array}$ & $\begin{array}{l}\text { Median } \\
\text { nitrate } \\
\text { concen- } \\
\text { tration, } \\
\text { in } \mathrm{mg} / \mathrm{L}\end{array}$ & $\begin{array}{l}\text { Percentage of } \\
\text { samples with } \\
\text { nitrate concen- } \\
\text { trations between } \\
3 \text { and } 10 \mathrm{mg} / \mathrm{L}\end{array}$ & $\begin{array}{l}\text { Percentage of } \\
\text { samples with } \\
\text { nitrate concen- } \\
\text { trations of at } \\
\text { least } 10 \mathrm{mg} / \mathrm{L}\end{array}$ & $\begin{array}{l}\text { Maximum } \\
\text { nitrate } \\
\text { concen- } \\
\text { tration, } \\
\text { in } \mathrm{mg} / \mathrm{L}\end{array}$ \\
\hline
\end{tabular}

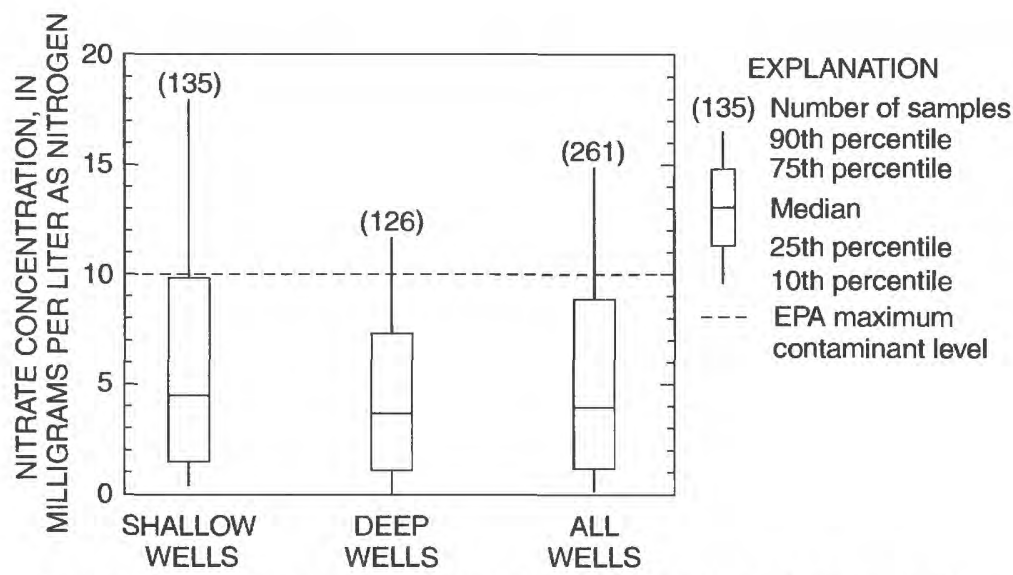

Figure 14a. The distribution of nitrate concentrations for groups of wells sampled in Grant County (categorized by ranges of well depths; see table 3 and table 13).

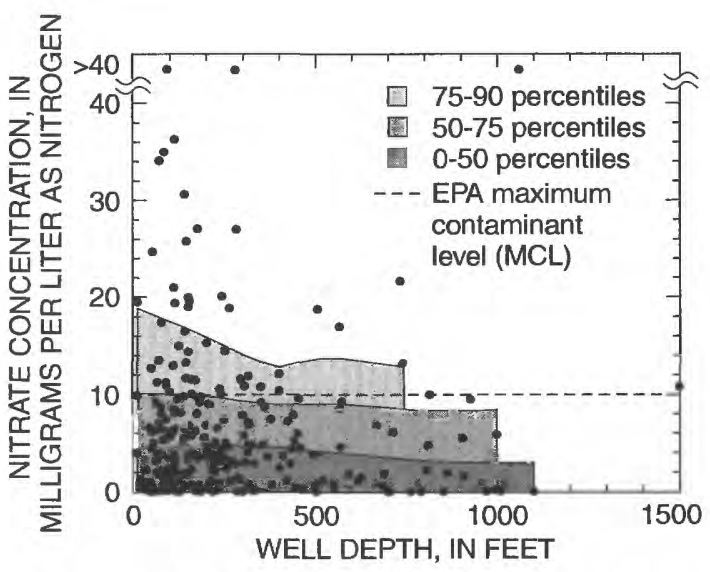

Figure 14b. Concentrations of nitrate in sampled wells, with lines representing moving 50th, 75th, and 90th percentiles of concentration for varying depths (estimated using the LOWESS method; see page 13). 


\section{Black Sands}

The baseline dataset for the Black Sands sampling region includes 28 samples obtained during the fall 1998 sampling event. Both the shallow and deep well categories are adequately represented with 11 and 17 samples, respectively (table 14).

Almost 50 percent of the shallow wells in the Black Sands sampling region exceed the MCL (fig. 15a), while only 12 percent of the deep wells exceed the MCL. In addition to having higher nitrate concentrations, the shallow wells also exhibited greater variability in concentrations of nitrate, with about 75 percent of the samples having nitrate concentrations less than $20 \mathrm{mg} / \mathrm{L}$, while 75 percent of the deeper wells had a nitrate concentration less than $6 \mathrm{mg} / \mathrm{L}$. There is a rapid decline in nitrate concentration with increasing depth over the first 200 feet of the subsurface (fig. 15b).

Table 14. Summary of nitrate concentrations in ground water, Black Sands, Grant County [mg/L, milligrams per liter; $\mathrm{ft}$, feet; \%, percent]

\begin{tabular}{|c|c|c|c|c|c|}
\hline & $\begin{array}{l}\text { Number } \\
\text { of } \\
\text { samples }\end{array}$ & $\begin{array}{l}\text { Median } \\
\text { nitrate } \\
\text { concen- } \\
\text { tration, } \\
\text { in } \mathrm{mg} / \mathrm{L}\end{array}$ & $\begin{array}{l}\text { Percentage of } \\
\text { samples with } \\
\text { nitrate concen- } \\
\text { trations between } \\
3 \text { and } 10 \mathrm{mg} / \mathrm{L}\end{array}$ & $\begin{array}{l}\text { Percentage of } \\
\text { samples with } \\
\text { nitrate concen- } \\
\text { trations of at } \\
\text { least } 10 \mathrm{mg} / \mathrm{L}\end{array}$ & $\begin{array}{l}\text { Maximum } \\
\text { nitrate } \\
\text { concen- } \\
\text { tration, } \\
\text { in } \mathrm{mg} / \mathrm{L}\end{array}$ \\
\hline All wells & 28 & 4.7 & $43 \%$ & $25 \%$ & 35 \\
\hline Wells less than $200 \mathrm{ft}$ deep & 11 & 9.8 & $36 \%$ & $46 \%$ & 35 \\
\hline Wells at least $200 \mathrm{ft}$ deep & 17 & 3.6 & $47 \%$ & $12 \%$ & 22 \\
\hline
\end{tabular}

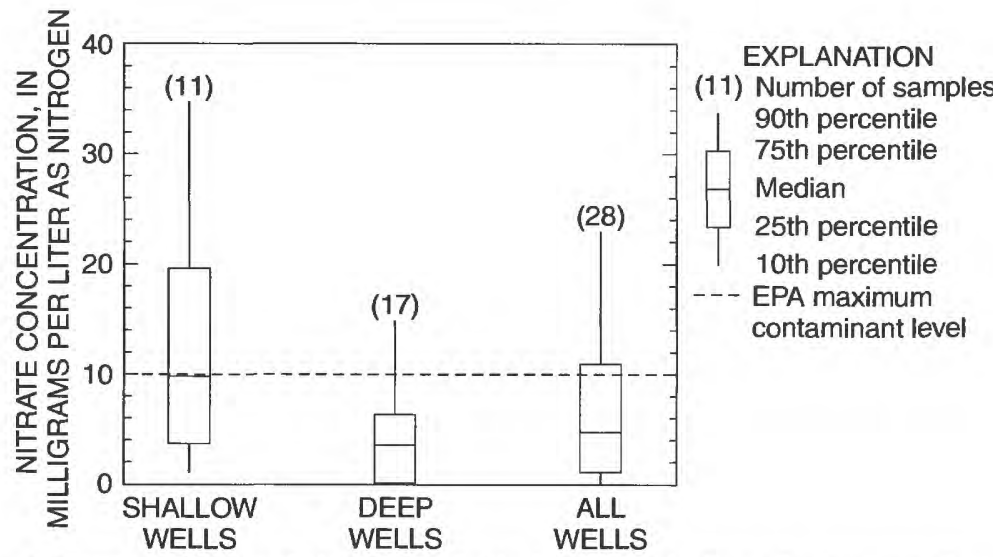

Figure 15a. The distribution of nitrate concentrations for groups of wells sampled in the Black Sands sampling region (categorized by ranges of well depths; see table 3 and table 14).

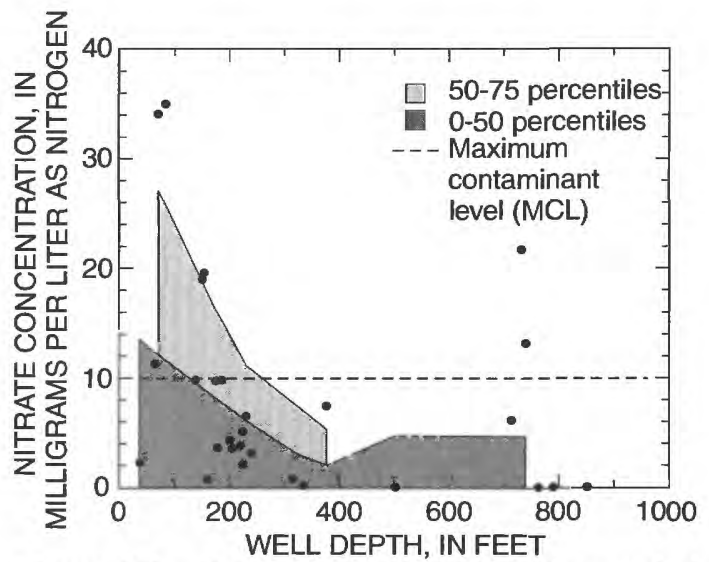

Figure 15b. Concentrations of nitrate in sampled wells, with lines representing moving 50 th and 75th percentiles of concentration for varying depths (estimated using the LOWESS method; see page 13). 


\section{Hartline}

The baseline dataset for the Hartline sampling region includes 38 samples obtained during the fall 1998 sampling event. Both the shallow and deep well categories are well represented, with 17 and 21 samples, respectively (table 15).

Shallow wells in the Hartline sampling region had a higher median and more variability in nitrate concentration than wells in the deep category (fig. 16a).
The majority of wells that exceeded the MCL concentration of $10 \mathrm{mg} / \mathrm{L}$ were less than 150 feet deep, and all wells that exceeded the MCL were less than 300 feet deep (fig. 16b). Nearly 29 percent of all the wells sampled in the Hartline sampling region had nitrate concentrations that exceeded the MCL.

Table 15. Summary of nitrate concentrations in ground water, Hartline, Grant County [mg/L, milligrams per liter; $\mathrm{ft}$, feet; \%, percent]

\begin{tabular}{|c|c|c|c|c|c|}
\hline & $\begin{array}{l}\text { Number } \\
\text { of } \\
\text { samples }\end{array}$ & $\begin{array}{l}\text { Median } \\
\text { nitrate } \\
\text { concen- } \\
\text { tration, } \\
\text { in } \mathrm{mg} / \mathrm{L}\end{array}$ & $\begin{array}{l}\text { Percentage of } \\
\text { samples with } \\
\text { nitrate concen- } \\
\text { trations between } \\
3 \text { and } 10 \mathrm{mg} / \mathrm{L}\end{array}$ & $\begin{array}{l}\text { Percentage of } \\
\text { samples with } \\
\text { nitrate concen- } \\
\text { trations of at } \\
\text { least } 10 \mathrm{mg} / \mathrm{L}\end{array}$ & $\begin{array}{l}\text { Maximum } \\
\text { nitrate } \\
\text { concen- } \\
\text { tration, } \\
\text { in } \mathrm{mg} / \mathrm{L}\end{array}$ \\
\hline All wells & 38 & 3.3 & $24 \%$ & $29 \%$ & 51 \\
\hline Wells less than $150 \mathrm{ft}$ deep & 17 & 6.3 & $18 \%$ & $41 \%$ & 51 \\
\hline Wells at least $150 \mathrm{ft}$ deep & 21 & 2.9 & $29 \%$ & $19 \%$ & 43 \\
\hline
\end{tabular}

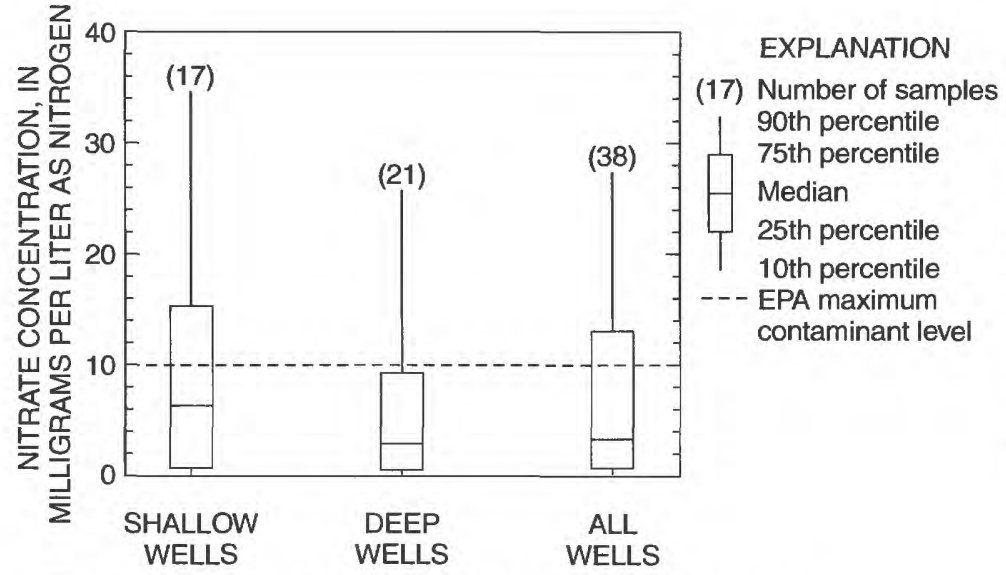

Figure 16a. The distribution of nitrate concentrations for groups of wells sampled in the Hartline sampling region (categorized by ranges of well depth; see tables 3 and 15).

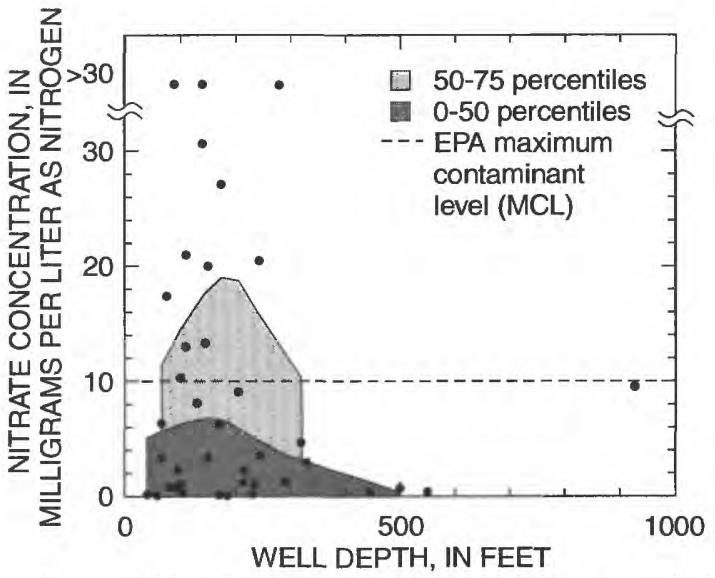

Figure 16b. Concentrations of nitrate in sampled wells, with lines representing moving 50th and 75th percentiles of concentration for varying depths (estimated using the LOWESS method; see page 13). 


\section{Mattawa}

The baseline dataset for the Mattawa sampling region includes 36 samples obtained during the fall 1998 sampling event. Both the shallow and deep well categories are well represented, with 20 and 16 samples, respectively (table 16).

In the Mattawa sampling region, the shallow well category had a higher median nitrate concentration, but the deep well category exhibited slightly greater variability in nitrate concentrations (fig. 17a). Additionally, a greater percentage of wells exceeded the MCL in the deep well category. Figure 17b appears to show a slight increase in nitrate concentration at depths of 150 to 300 feet, but there are too few data in that range to support any firm conclusions along these lines.

Table 16. Summary of nitrate concentrations in ground water, Mattawa, Grant County [mg/L, milligrams per liter; ft, feet; $\%$, percent]

\begin{tabular}{lcllll}
\hline & $\begin{array}{l}\text { Median } \\
\text { nitrate } \\
\text { of } \\
\text { samples } \\
\text { tration, } \\
\text { in } \mathrm{mg} / \mathrm{L}\end{array}$ & $\begin{array}{l}\text { Percentage of } \\
\text { samples with } \\
\text { nitrate concen- } \\
\text { trations between } \\
3 \text { and } 10 \mathrm{mg} / \mathrm{L}\end{array}$ & $\begin{array}{l}\text { Percentage of } \\
\text { samples with } \\
\text { nitrate concen- } \\
\text { trations of at } \\
\text { least } 10 \mathrm{mg} / \mathrm{L}\end{array}$ & $\begin{array}{l}\text { Maximum } \\
\text { nitrate } \\
\text { concen- } \\
\text { tration, } \\
\text { in } \mathrm{mg} / \mathrm{L}\end{array}$ \\
\hline $\begin{array}{l}\text { All wells } \\
\text { Wells less than 200 ft deep }\end{array}$ & 20 & 1.9 & $31 \%$ & $14 \%$ & 19 \\
Wells at least 200 $\mathrm{ft}$ deep & 16 & 1.7 & $35 \%$ & $10 \%$ & 17 \\
\end{tabular}

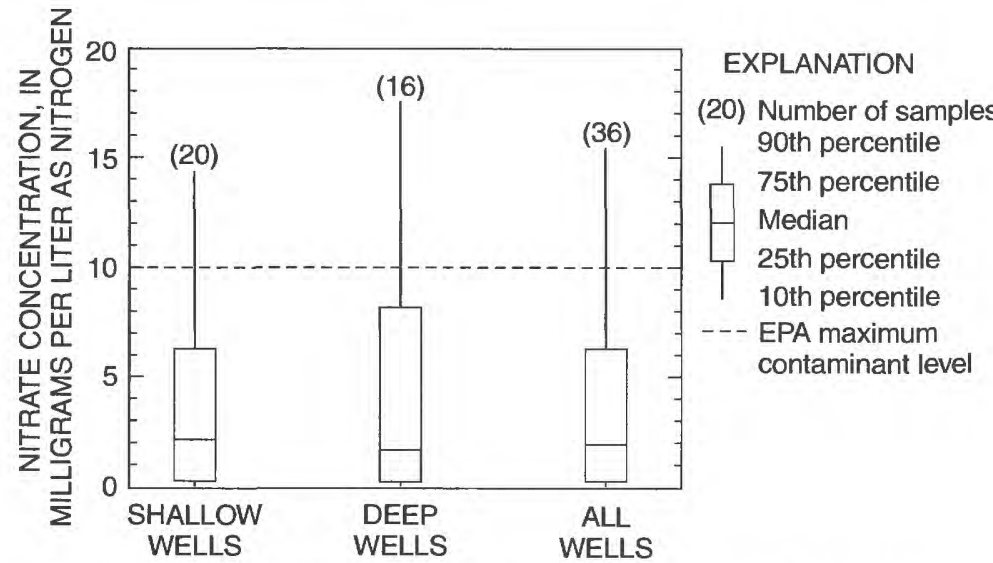

Figure 17a. The distribution of nitrate concentrations for groups of wells sampled in the Mattawa sampling region (categorized by ranges of well depths; see table 3 and table 16).

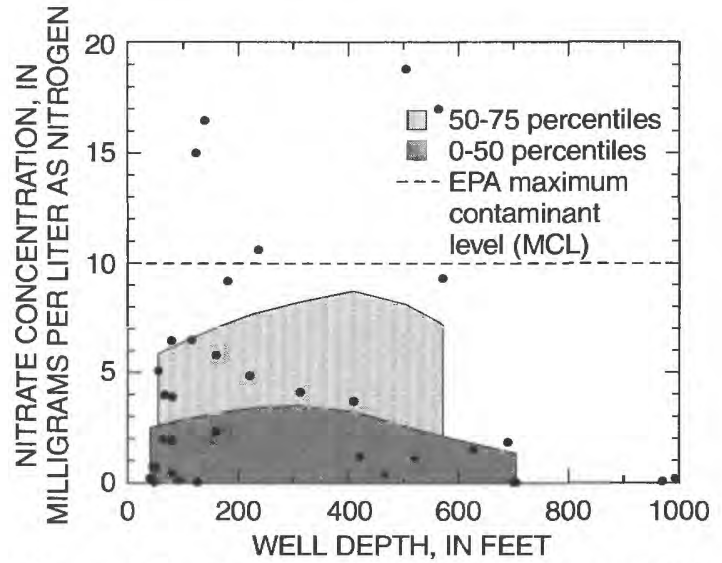

Figure 17b. Concentrations of nitrate in sampled wells, with lines representing moving 50th and 75th percentiles of concentration for varying depths (estimated using the LOWESS method; see page 13). 


\section{Moses Lake}

The baseline dataset for the Moses Lake sampling region includes 34 samples obtained during the fall 1998 sampling event. Both the shallow and deep well categories are well represented, with 18 and 16 samples, respectively (table 17).

Shallow wells in the Moses Lake sampling region had a higher median nitrate concentration than deeper wells (fig. 18a). Seventy-five percent of the wells in the shallow depth category had a nitrate concentration less than $7 \mathrm{mg} / \mathrm{L}$, while 75 percent of the wells in the deep well category had a nitrate concentration below $5 \mathrm{mg} / \mathrm{L}$. There was a gradual decline in the lower 50 percent of nitrate concentrations as the depth of the wells increased (fig. 18b).

Table 17. Summary of nitrate concentrations in ground water, Moses Lake, Grant County [mg/L, milligrams per liter; $\mathrm{ft}$, feet; \%, percent]

\begin{tabular}{|c|c|c|c|c|c|}
\hline & $\begin{array}{l}\text { Number } \\
\text { of } \\
\text { samples }\end{array}$ & $\begin{array}{l}\text { Median } \\
\text { nitrate } \\
\text { concen- } \\
\text { tration, } \\
\text { in } \mathrm{mg} / \mathrm{L}\end{array}$ & $\begin{array}{l}\text { Percentage of } \\
\text { samples with } \\
\text { nitrate concen- } \\
\text { trations between } \\
3 \text { and } 10 \mathrm{mg} / \mathrm{L}\end{array}$ & $\begin{array}{l}\text { Percentage of } \\
\text { samples with } \\
\text { nitrate concen- } \\
\text { trations of at } \\
\text { least } 10 \mathrm{mg} / \mathrm{L}\end{array}$ & $\begin{array}{l}\text { Maximum } \\
\text { nitrate } \\
\text { concen- } \\
\text { tration, } \\
\text { in } \mathrm{mg} / \mathrm{L}\end{array}$ \\
\hline All wells & 34 & 3.3 & $35 \%$ & $18 \%$ & 36 \\
\hline Wells less than $200 \mathrm{ft}$ deep & 18 & 3.8 & $44 \%$ & $17 \%$ & 36 \\
\hline Wells at least $200 \mathrm{ft}$ deep & 16 & 2.3 & $25 \%$ & $19 \%$ & 27 \\
\hline
\end{tabular}

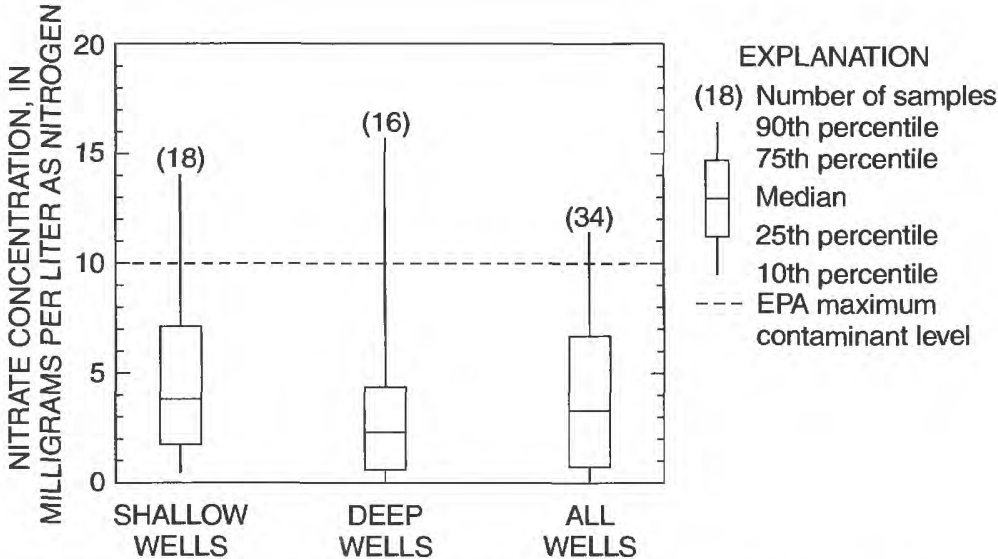

Figure 18a. The distribution of nitrate concentrations for groups of wells sampled in the Moses Lake sampling region (categorized by ranges of well depths; see tables 3 and 17).

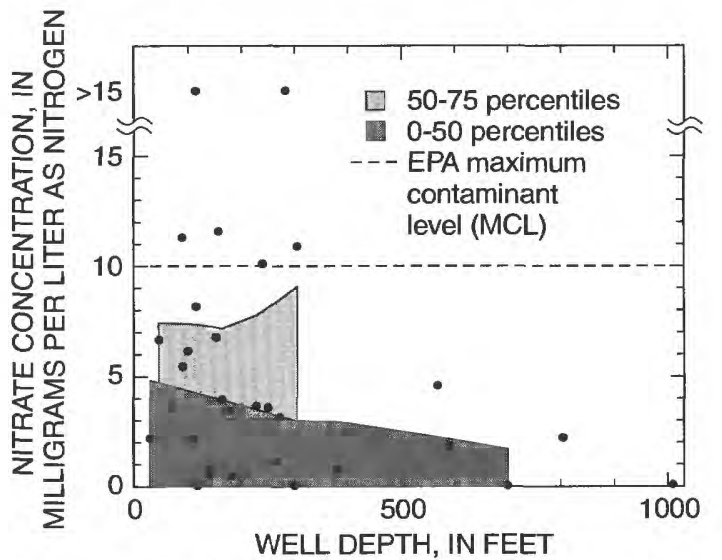

Figure 18b. Concentrations of nitrate in sampled wells, with lines representing moving 50th and 75th percentiles of concentration for varying depths (estimated using the LOWESS method; see page 13). 


\section{Quincy/Ephrata}

The baseline dataset for the Quincy/Ephrata sampling region includes 41 samples obtained during the fall 1998 sampling event. Both the shallow and deep well categories are well represented, with 21 and 20 samples, respectively (table 18).

The shallow well category exhibits more variability in the concentrations of nitrate than does the deep well category (fig. 19a). Fifty percent of the wells had nitrate concentrations between 2 and $7 \mathrm{mg} / \mathrm{L}$ in the shallow well category, while 50 percent of the deep wells had concentrations between 3 and $6 \mathrm{mg} / \mathrm{L}$.

Nitrate concentrations in the Quincy/Ephrata sampling region appear to increase with depth (fig. 19b), although the shallow depth category had the only sample that exceeded the MCL. All concentrations in the deep well category were below the MCL.

Table 18. Summary of nitrate concentrations in ground water, Quincy/Ephrata, Grant County [mg/L, milligrams per liter; $\mathrm{ft}$, feet; \%, percent]

$\begin{array}{lllll} & \begin{array}{l}\text { Median } \\ \text { nitrate }\end{array} & \begin{array}{l}\text { Percentage of } \\ \text { samples with }\end{array} & \begin{array}{l}\text { Percentage of } \\ \text { samples with }\end{array} & \begin{array}{l}\text { Maximum } \\ \text { nitrate }\end{array} \\ \begin{array}{l}\text { Number } \\ \text { of }\end{array} & \begin{array}{l}\text { concen- } \\ \text { tration, }\end{array} & \begin{array}{l}\text { nitrate concen- } \\ \text { trations between }\end{array} & \begin{array}{l}\text { nitrate concen- } \\ \text { trations of at }\end{array} & \begin{array}{l}\text { concen- } \\ \text { tration, }\end{array} \\ \text { samples } & \text { in } \mathrm{mg} / \mathrm{L} & 3 \text { and } 10 \mathrm{mg} / \mathrm{L} & \text { least } 10 \mathrm{mg} / \mathrm{L} & \text { in } \mathrm{mg} / \mathrm{L}\end{array}$

All wells

Wells less than $150 \mathrm{ft}$ deep

Wells at least $150 \mathrm{ft}$ deep
41

21

20
3.9

3.9

4.1
$68 \%$

$57 \%$

$80 \%$
$5 \%$

$10 \%$

$0 \%$
26

26

8.6

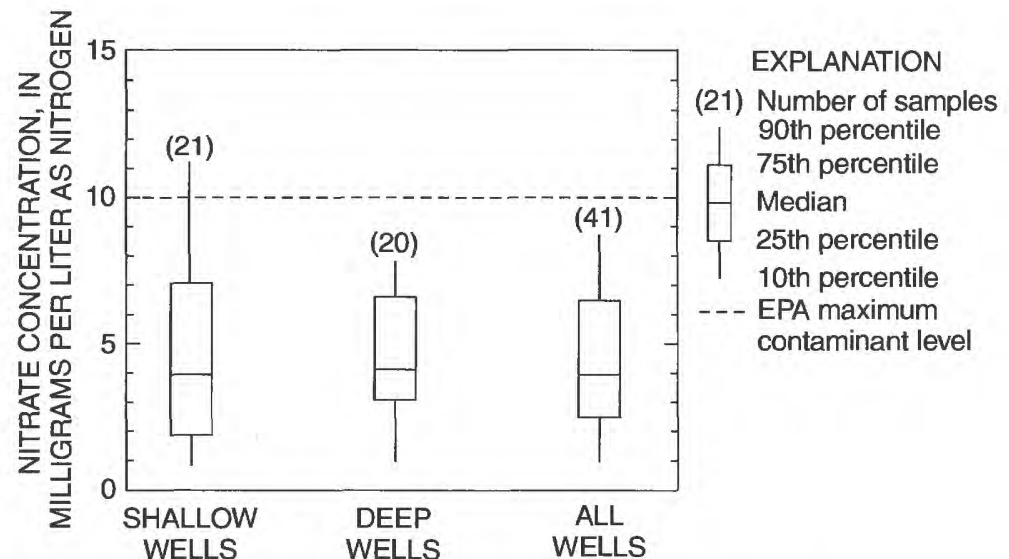

Figure 19a. The distribution of nitrate concentrations for groups of wells sampled in the Quincy/Ephrata sampling region

(categorized by ranges of well depths; see tables 3 and 18).

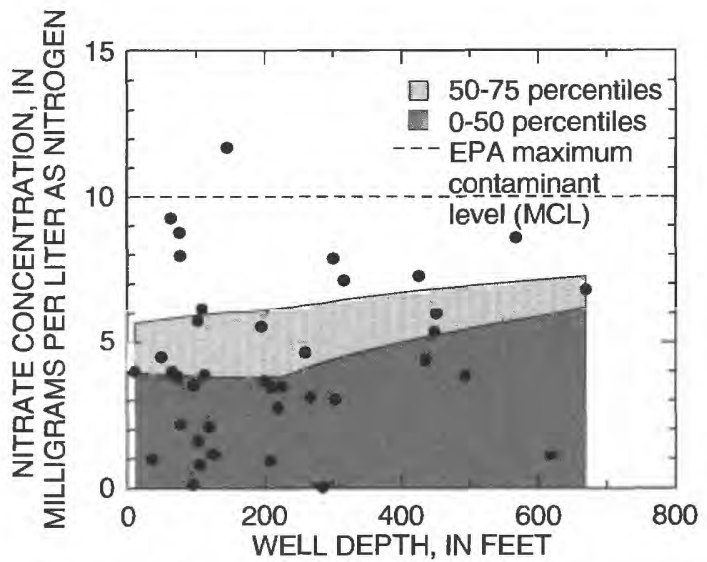

Figure 19b. Concentrations of nitrate in sampled wells, with lines representing moving 50th and 75th percentiles of concentration for varying depths (estimated using the LOWESS method; see page 13 ). 


\section{Royal Slope}

The baseline dataset for the Royal Slope sampling region includes 42 samples obtained during the fall 1998 sampling event. Both the shallow and deep well categories are well represented, with 23 and 19 samples, respectively (table 19).

The median nitrate concentrations for both the shallow and deep wells are quite similar in the Royal Slope sampling region (fig. 20a). In the deep depth category, about 75 percent of the wells had concentrations belów $9 \mathrm{mg} / \mathrm{L}$, while 75 percent of the wells in the shallow depth category had concentrations below $10 \mathrm{mg} / \mathrm{L}$. In figure 20b, the lack of data on wells between 500 and 800 feet deep makes it difficult to interpolate an accurate change in nitrate concentrations in relation to depth. Overall, approximately 19 percent of the wells sampled in the Royal Slope sampling region had nitrate concentrations exceeding the MCL of $10 \mathrm{mg} / \mathrm{L}$.

Table 19. Summary of nitrate concentrations in ground water, Royal Slope, Grant County [mg/L, milligrams per liter; $\mathrm{ft}$, feet; \%, percent]

\begin{tabular}{|c|c|c|c|c|}
\hline $\begin{array}{l}\text { Number } \\
\text { of } \\
\text { samples }\end{array}$ & $\begin{array}{l}\text { Median } \\
\text { nitrate } \\
\text { concen- } \\
\text { tration, } \\
\text { in } \mathrm{mg} / \mathrm{L}\end{array}$ & $\begin{array}{l}\text { Percentage of } \\
\text { samples with } \\
\text { nitrate concen- } \\
\text { trations between } \\
3 \text { and } 10 \mathrm{mg} / \mathrm{L}\end{array}$ & $\begin{array}{l}\text { Percentage of } \\
\text { samples with } \\
\text { nitrate concen- } \\
\text { trations of at } \\
\text { least } 10 \mathrm{mg} / \mathrm{L}\end{array}$ & $\begin{array}{l}\text { Maximum } \\
\text { nitrate } \\
\text { concen- } \\
\text { tration, } \\
\text { in } \mathrm{mg} / \mathrm{L}\end{array}$ \\
\hline
\end{tabular}

All wells 42

Wells less than $150 \mathrm{ft}$ deep

23

5.6

$48 \%$

$19 \%$

Wells at least $150 \mathrm{ft}$ deep

19

6.2

$39 \%$

$28 \%$

25

5.5

$58 \%$

$16 \%$

56

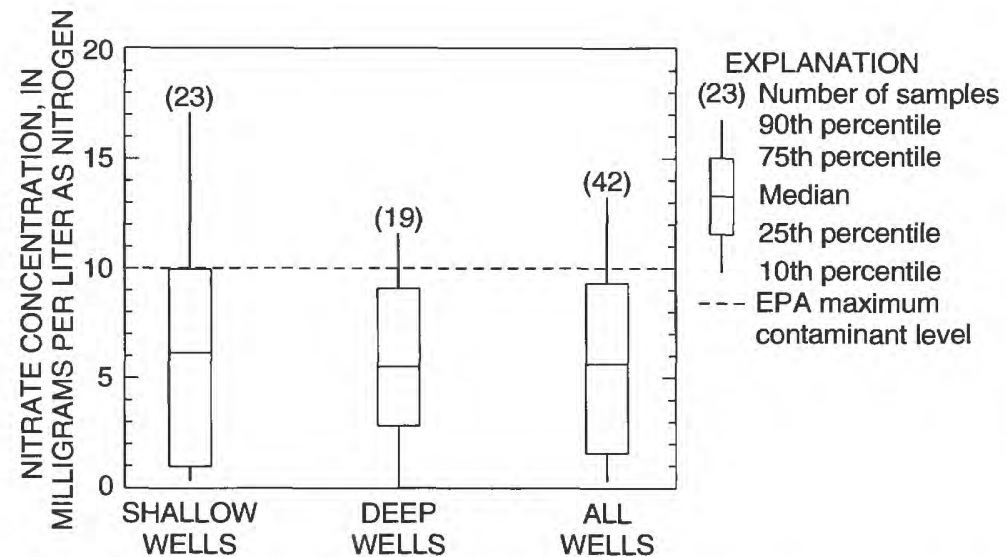

Figure 20a. The distribution of nitrate concentrations for groups of wells sampled in the Royal Slope sampling region (categorized by ranges of well depths; see tables 3 and 19).

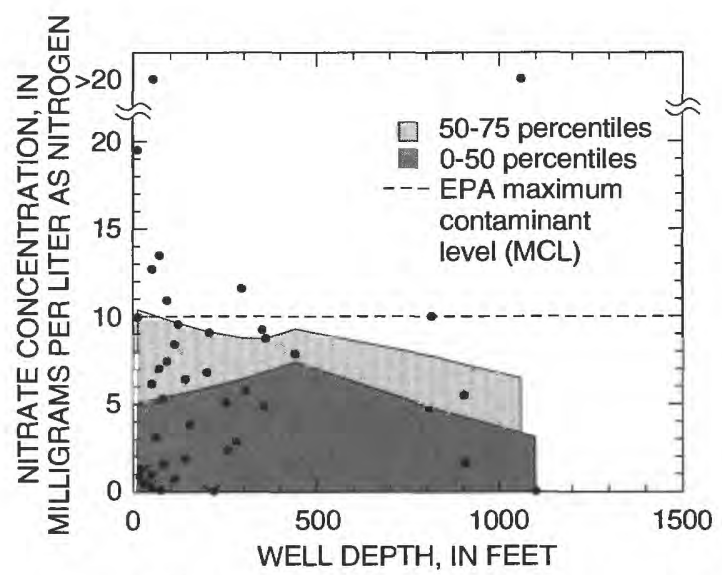

Figure 20b. Concentrations of nitrate in sampled wells, with lines representing moving 50th and 75th percentiles of concentration for varying depths (estimated using the LOWESS method; see page 13). 


\section{Warden}

The baseline dataset for the Warden sampling region includes 42 samples obtained during the fall 1998 sampling event. Both the shallow and deep well categories are well represented, with 25 and 17 samples, respectively (table 20).

In the Warden sampling region, the shallow and deep well categories have similar median nitrate concentrations and variability in concentrations (fig. 21a). However, the shallow wells do have a slightly higher median concentration, and the upper 25 percent of the samples in the shallow well category span a wider range of concentrations than in the deep well category. For both depth categories, approximately 30 percent of the wells had nitrate concentrations that exceeded $10 \mathrm{mg} / \mathrm{L}$. Most of the sampled wells were less than 500 feet in depth (fig. 21b).

Table 20. Summary of nitrate concentrations in ground water, Warden, Grant County [mg/L, milligrams per liter; ft, feet; \%, percent]

\begin{tabular}{llllll}
\hline & $\begin{array}{l}\text { Number } \\
\text { of } \\
\text { samples } \\
\text { nitrate } \\
\text { concen- } \\
\text { tration, } \\
\text { in mg/L }\end{array}$ & $\begin{array}{l}\text { Percentage of } \\
\text { samples with } \\
\text { nitrate concen- } \\
\text { trations between } \\
3 \text { and } 10 \mathrm{mg} / \mathrm{L}\end{array}$ & $\begin{array}{l}\text { Percentage of } \\
\text { samples with } \\
\text { nitrate concen- } \\
\text { trations of at } \\
\text { least } 10 \mathrm{mg} / \mathrm{L}\end{array}$ & $\begin{array}{l}\text { Maximum } \\
\text { nitrate } \\
\text { concen- } \\
\text { tration, } \\
\text { in mg/L }\end{array}$ \\
\hline $\begin{array}{l}\text { All wells } \\
\text { Wells less than } 300 \mathrm{ft} \text { deep }\end{array}$ & 25 & 5.7 & $38 \%$ & $29 \%$ & 19 \\
Wells at least 300 ft deep & 17 & 4.9 & $40 \%$ & $28 \%$ & 19 \\
\end{tabular}

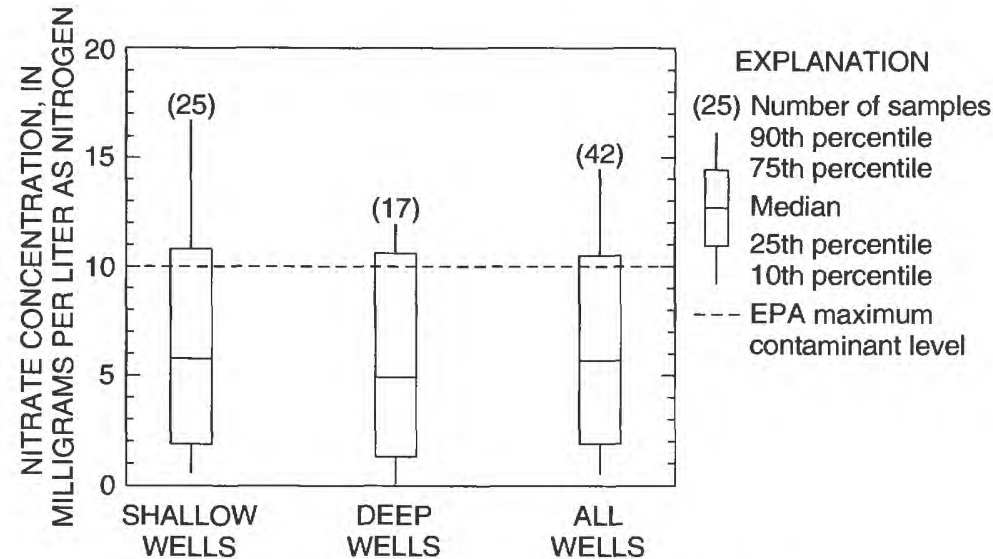

Figure 21a. The distribution of nitrate concentrations for groups of wells sampled in the Warden sampling region (categorized by ranges of well depths; see tables 3 and 20).

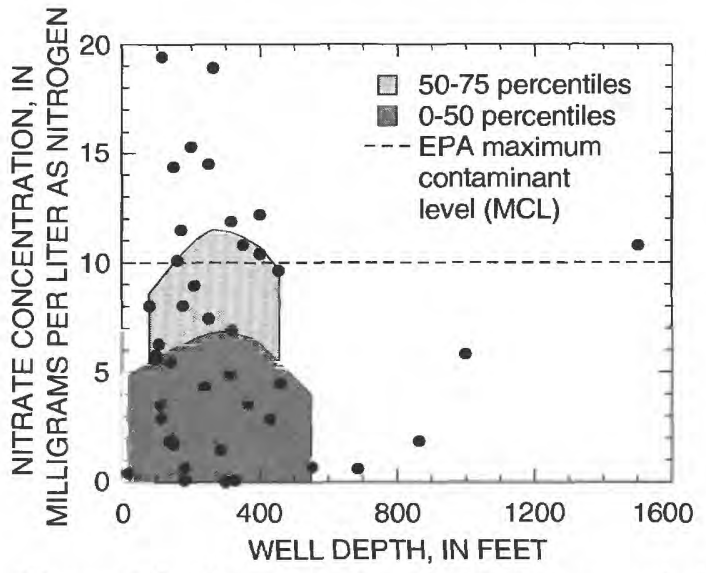

Figure 21b. Concentrations of nitrate in sampled wells, with lines representing moving 50th and 75th percentiles of concentration for varying depths (estimated using the LOWESS method; see page 13). 
ADAMS COUNTY

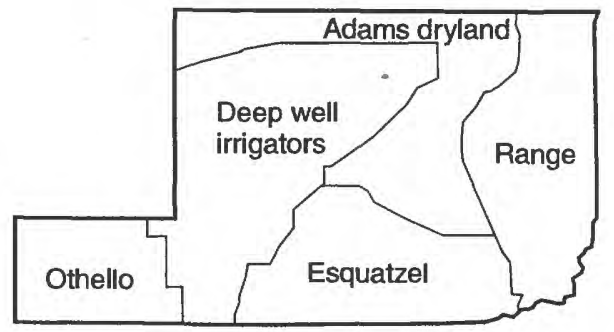

Figure 22. Sampling region boundaries in Adams County.
The fall 1998 mass sampling for nitrate included 133 wells in Adams County (table 21), distributed among the 5 sampling regions (fig. 22).

There was a dramatic decrease in nitrate concentrations between the shallow and deep depth categories (fig. $23 \mathrm{a})$. Over 30 percent of the shallow wells sampled had a concentration above $10 \mathrm{mg} / \mathrm{L}$, while only 11 percent of the deep wells sampled exceeded $10 \mathrm{mg} / \mathrm{L}$. The largest drop in nitrate concentrations occurred over the first 300 feet of the subsurface (fig. 23b).

Table 21. Summary of nitrate concentrations in ground water, Adams County [mg/L, milligrams per liter; \%, percent]

\begin{tabular}{|c|c|c|c|c|}
\hline $\begin{array}{l}\text { Number } \\
\text { of } \\
\text { samples }\end{array}$ & $\begin{array}{l}\text { Median } \\
\text { nitrate } \\
\text { concen- } \\
\text { tration, } \\
\text { in } \mathrm{mg} / \mathrm{L}\end{array}$ & $\begin{array}{l}\text { Percentage of } \\
\text { samples with } \\
\text { nitrate concen- } \\
\text { trations between } \\
3 \text { and } 10 \mathrm{mg} / \mathrm{L}\end{array}$ & $\begin{array}{l}\text { Percentage of } \\
\text { samples with } \\
\text { nitrate concen- } \\
\text { trations of at } \\
\text { least } 10 \mathrm{mg} / \mathrm{L}\end{array}$ & $\begin{array}{l}\text { Maximum } \\
\text { nitrate } \\
\text { concen- } \\
\text { tration, } \\
\text { in } \mathrm{mg} / \mathrm{L}\end{array}$ \\
\hline
\end{tabular}

\begin{tabular}{lrllll} 
All wells & 133 & 3.7 & $34 \%$ & $21 \%$ & 77 \\
Shallow wells & 68 & 5.7 & $40 \%$ & $31 \%$ & 77 \\
Deep wells & 63 & 1.6 & $27 \%$ & $11 \%$ & 19 \\
\hline
\end{tabular}

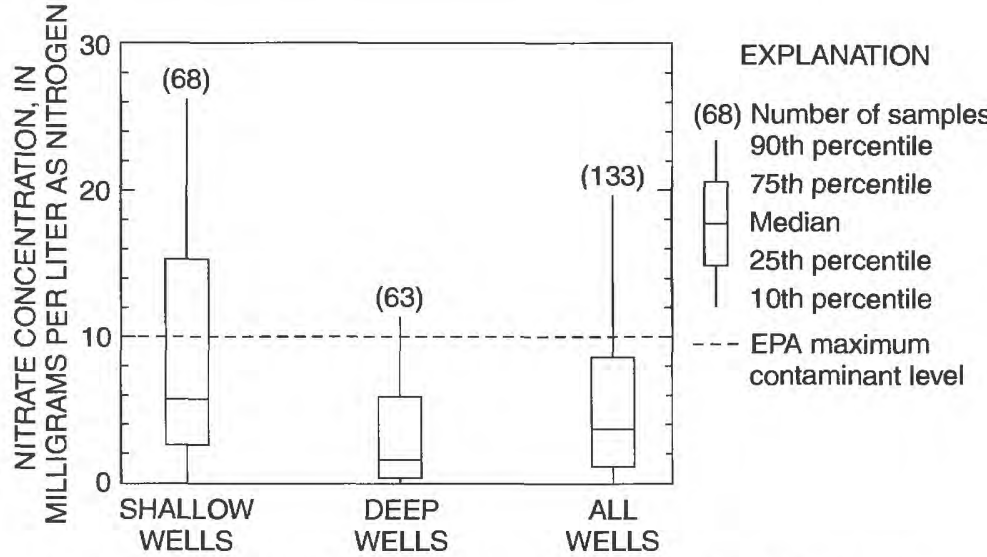

Figure 23a. The distribution of nitrate concentrations for groups of wells sampled in Adams County (categorized by ranges of well depths; see table 3 and table 21).

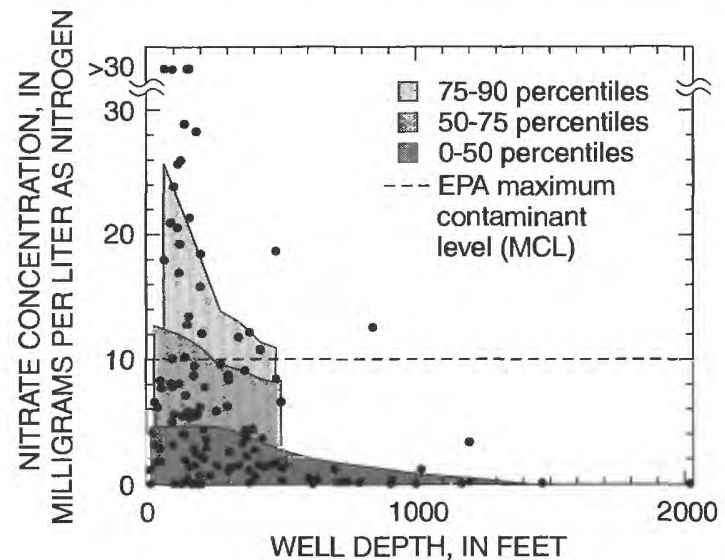

Figure 23b. Concentrations of nitrate in sampled wells, with lines representing moving 50th,75th, and 90 th percentiles of concentration for varying depths (estimated using the LOWESS method; see page 13). 


\section{Adams Dryland}

The baseline dataset for the Adams dryland sampling region includes 30 samples obtained during the fall 1998 sampling event. Shallow wells are well represented, with 17 samples in this dataset; deep wells are adequately represented, with 13 samples (table 22).

Shallow wells in the Adams dryland sampling region had a higher median and greater variability in nitrate concentrations than wells in the deep well category (fig. 24a). Seventy-five percent of the wells in the deep category had a concentration below $10 \mathrm{mg} / \mathrm{L}$ while 75 percent of wells in the shallow category had concentrations below $25 \mathrm{mg} / \mathrm{L}$. Overall, one third of all wells sampled in the Adams dryland sampling region exceeded the MCL of $10 \mathrm{mg} / \mathrm{L}$. There appears to be a steady decline in nitrate concentrations with increasing depth (fig. 24b). The drop is steepest for wells with nitrate concentrations above $10 \mathrm{mg} / \mathrm{L}$ and depths less than 200 feet.

Table 22. Summary of nitrate concentrations in ground water, Adams dryland, Adams County [mg/L, milligrams per liter; ft, feet; $\%$, percent]

\begin{tabular}{llllll}
\hline & $\begin{array}{l}\text { Number } \\
\text { of } \\
\text { samples }\end{array}$ & $\begin{array}{l}\text { Median } \\
\text { nitrate } \\
\text { concen- } \\
\text { tration, } \\
\text { in } \mathrm{mg} / \mathrm{L}\end{array}$ & $\begin{array}{l}\text { Percentage of } \\
\text { samples with } \\
\text { nitrate concen- } \\
\text { trations between } \\
3 \text { and } 10 \mathrm{mg} / \mathrm{L}\end{array}$ & $\begin{array}{l}\text { Percentage of } \\
\text { samples with } \\
\text { nitrate concen- } \\
\text { trations of at } \\
\text { least } 10 \mathrm{mg} / \mathrm{L}\end{array}$ & $\begin{array}{l}\text { Maximum } \\
\text { nitrate } \\
\text { concen- } \\
\text { tration, } \\
\text { in } \mathrm{mg} / \mathrm{L}\end{array}$ \\
\hline $\begin{array}{l}\text { All wells } \\
\text { Wells less than 200 ft deep }\end{array}$ & 30 & 5.4 & $33 \%$ & $33 \%$ & 56 \\
Wells at least 200 ft deep & 13 & 5.9 & $41 \%$ & $41 \%$ & 56 \\
\end{tabular}

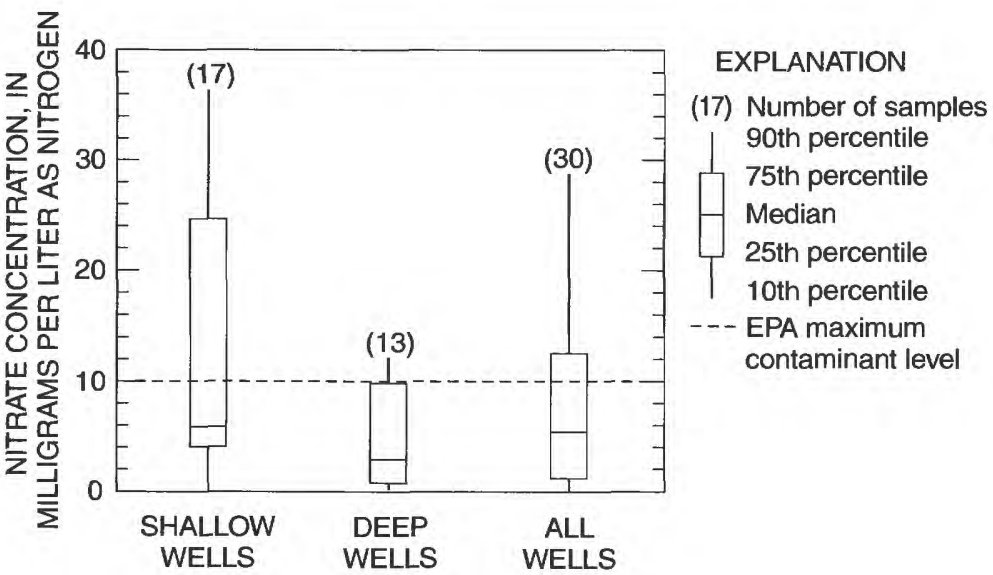

Figure 24a. The distribution of nitrate concentrations for groups of wells sampled in the Adams dryland sampling region (categorized by ranges of well depths; see table 3 and table 22).

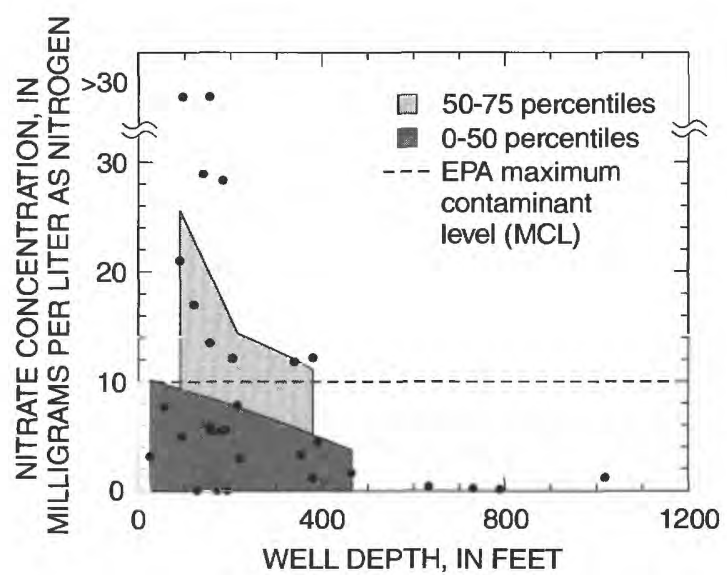

Figure 24b. Concentrations of nitrate in sampled wells, with lines representing moving 50 th and 75th percentiles of concentration for varying depths (estimated using the LOWESS method; see page 13). 


\section{Deep Well Irrigators}

The baseline dataset for the Deep well irrigators sampling region includes 37 samples obtained during the fall 1998 sampling event. Both the shallow and deep well categories are well represented, with 18 samples each (table 23).

Shallow wells in the Deep well irrigator sampling region had a higher median and greater variability in nitrate concentrations than deeper wells (fig. 25a). Seventy-five percent of the wells in the deep category had a concentration below $5 \mathrm{mg} / \mathrm{L}$, while 75 percent of wells in the shallow category had concentrations below $7 \mathrm{mg} / \mathrm{L}$. Overall, 16 percent of all wells sampled in the Deep well irrigators sampling region exceeded the MCL of $10 \mathrm{mg} / \mathrm{L}$. There appears to be a steady decline in nitrate concentrations with increasing depth (fig. 25b).

Table 23. Summary of nitrate concentrations in ground water, Deep well irrigators, Adams County [mg/L, milligrams per liter; $\mathrm{ft}$, feet; $\%$, percent]

\begin{tabular}{llllll}
\hline & & $\begin{array}{l}\text { Median } \\
\text { nitrate } \\
\text { concen- } \\
\text { tration, } \\
\text { in } \mathrm{mg} / \mathrm{L}\end{array}$ & $\begin{array}{l}\text { Percentage of } \\
\text { samples with } \\
\text { nitrate concen- } \\
\text { samples } \\
\text { trations between } \\
3 \text { and } 10 \mathrm{mg} / \mathrm{L}\end{array}$ & $\begin{array}{l}\text { Percentage of } \\
\text { samples with } \\
\text { nitrate concen- } \\
\text { trations of at } \\
\text { least } 10 \mathrm{mg} / \mathrm{L}\end{array}$ & $\begin{array}{l}\text { Maximum } \\
\text { nitrate } \\
\text { concen- } \\
\text { tration, } \\
\text { in } \mathrm{mg} / \mathrm{L}\end{array}$ \\
\hline $\begin{array}{l}\text { All wells } \\
\text { Wells less than 200 ft deep }\end{array}$ & 37 & 1.2 & $19 \%$ & $16 \%$ & 26 \\
Wells at least 200 ft deep & 18 & 2.7 & $22 \%$ & $22 \%$ & 26 \\
& 0.3 & $17 \%$ & $11 \%$ & 19 \\
\hline
\end{tabular}

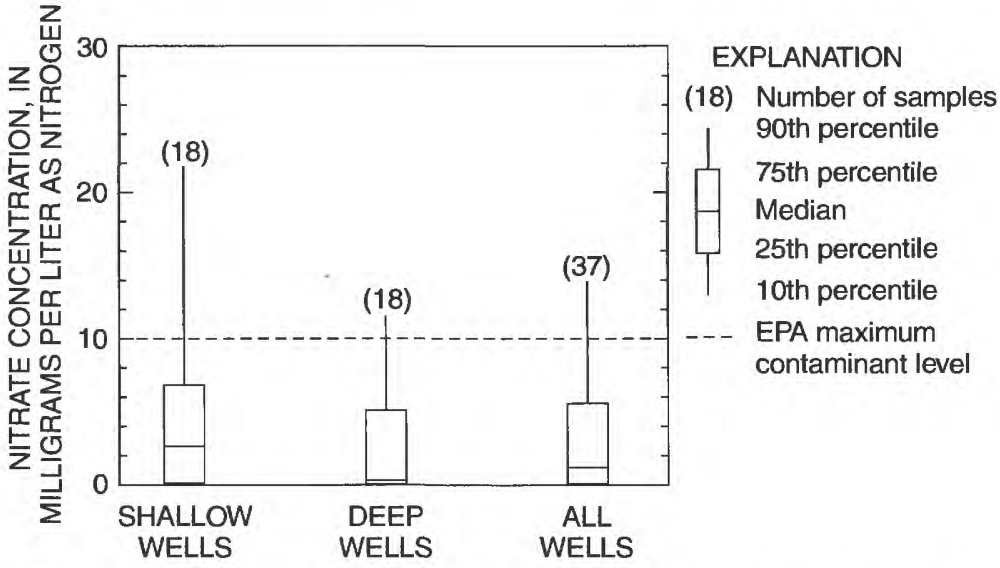

Figure 25a. The distribution of nitrate concentrations for groups of wells sampled in the Deep well irrigators sampling region (categorized by ranges of well depths; see tables 3 and 23).

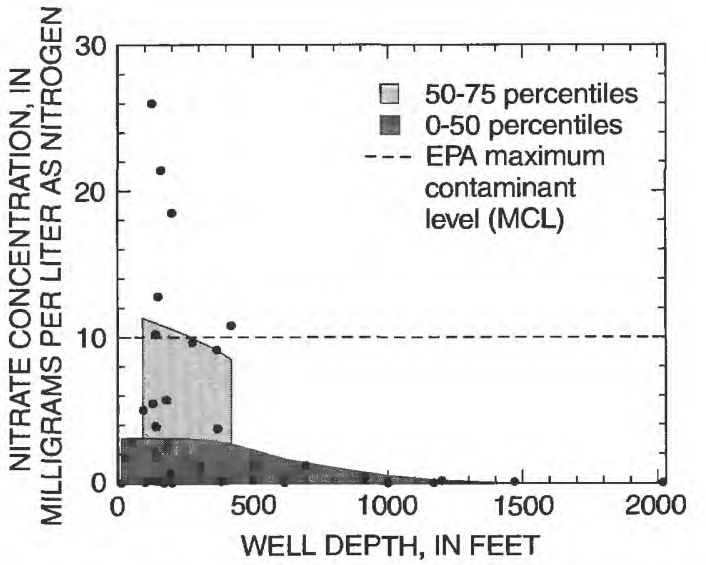

Figure 25b. Concentrations of nitrate in sampled wells, with lines representing moving 50th and 75th percentiles of concentration for varying depths (estimated using the LOWESS method; see page 13). 


\section{Esquatzel}

The baseline dataset for the Esquatzel sampling region includes 21 samples obtained during the fall 1998 sampling event. Deep wells are adequately represented by 13 samples in this dataset. However, only eight samples were available in the shallow well category, giving summary statistics for this group less certainty (table 24).

Shallow wells in the Esquatzel sampling region had a much higher median nitrate concentration than the deep wells (table 24), and over 75 percent of the wells in the deep category had a concentration less than $10 \mathrm{mg} / \mathrm{L}$ (fig. 26a). Only eight shallow wells were sampled; based on this small dataset, the shallow group of wells exhibited greater variability in concentration than did the deeper group of wells (figs. 26a and 26b). Additional data would be desirable to state these relations with greater confidence.

Table 24. Summary of nitrate concentrations in ground water, Esquatzel, Adams County [mg/L, milligrams per liter; $\mathrm{ft}$, feet; $\%$, percent]

\begin{tabular}{|c|c|c|c|c|c|}
\hline & $\begin{array}{l}\text { Number } \\
\text { of } \\
\text { samples }\end{array}$ & $\begin{array}{l}\text { Median } \\
\text { nitrate } \\
\text { concen- } \\
\text { tration, } \\
\text { in } \mathrm{mg} / \mathrm{L}\end{array}$ & $\begin{array}{l}\text { Percentage of } \\
\text { samples with } \\
\text { nitrate concen- } \\
\text { trations between } \\
3 \text { and } 10 \mathrm{mg} / \mathrm{L}\end{array}$ & $\begin{array}{l}\text { Percentage of } \\
\text { samples with } \\
\text { nitrate concen- } \\
\text { trations of at } \\
\text { least } 10 \mathrm{mg} / \mathrm{L}\end{array}$ & $\begin{array}{l}\text { Maximum } \\
\text { nitrate } \\
\text { concen- } \\
\text { tration, } \\
\text { in } \mathrm{mg} / \mathrm{L}\end{array}$ \\
\hline All wells & 21 & 5.7 & $38 \%$ & $24 \%$ & 77 \\
\hline Wells less than $200 \mathrm{ft}$ deep & 8 & 14 & $50 \%$ & $50 \%$ & 77 \\
\hline Wells at least $200 \mathrm{ft}$ deep & 13 & 1.5 & $31 \%$ & $8 \%$ & 19 \\
\hline
\end{tabular}

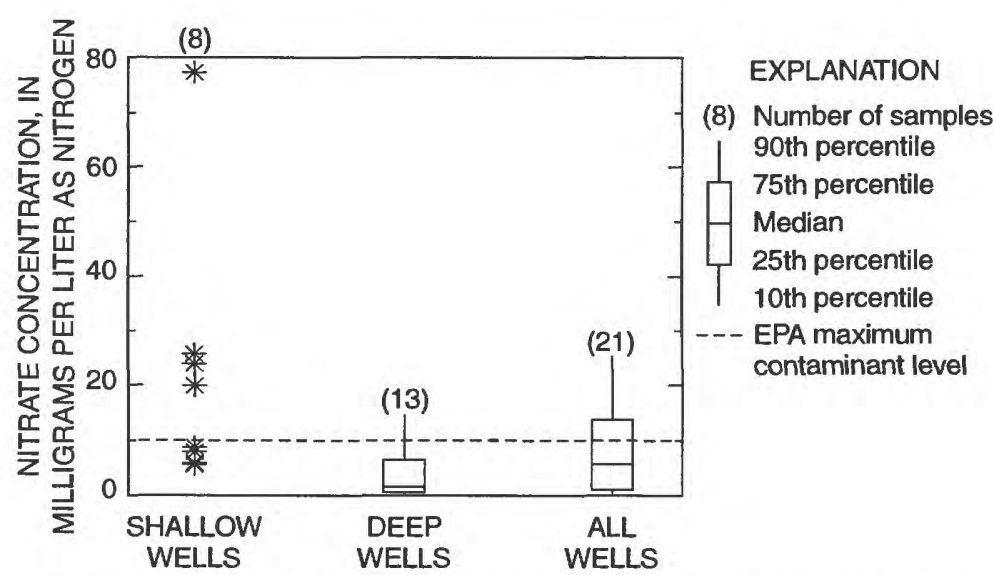

Figure 26a. The distribution of nitrate concentrations for groups of wells sampled in the Esquatzel sampling region (categorized by ranges of well depths; see table 3 and table 24). Insufficient data were available for the shallow well category so individual data points are plotted.

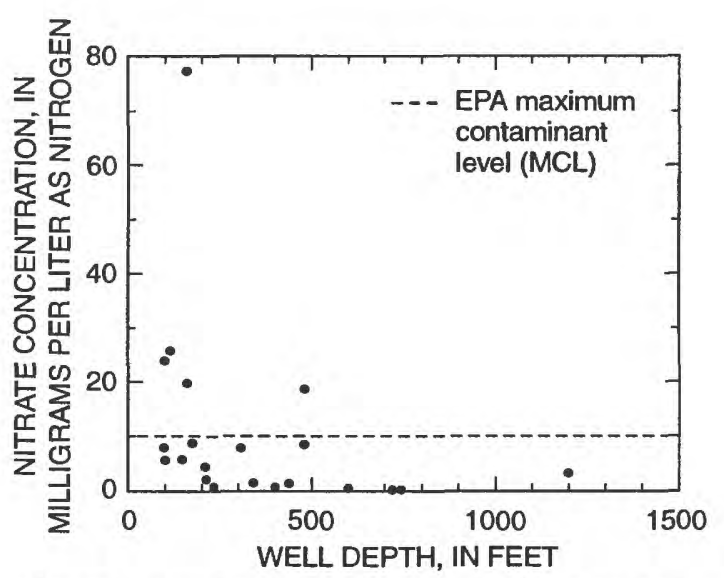

Figure 26b. Concentrations of nitrate in sampled wells. Insufficient data were available to draw LOWESS curves. 


\section{Othello}

The baseline dataset for the Othello sampling region includes 36 samples obtained during the fall 1998 sampling event. Both the shallow and deep well categories are well represented, with 20 and 16 samples, respectively (table 25 ).

Shallow wells in the Othello sampling region had a higher median and greater variability in nitrate concentrations than deeper wells (fig. 27a).
Seventy-five percent of the wells in the deep category had a concentration below $6 \mathrm{mg} / \mathrm{L}$, while 75 percent of wells in the shallow category had concentrations below $9 \mathrm{mg} / \mathrm{L}$. Overall, 14 percent of all wells sampled in the Othello sampling region exceeded the MCL of $10 \mathrm{mg} / \mathrm{L}$. There appears to be a steady decline in nitrate concentrations with increasing depth for concentrations at or below the 75 th percentile (fig. $27 \mathrm{~b}$ ).

Table 25. Summary of nitrate concentrations in ground water, Othello, Adams County [mg/L, milligrams per liter; ft, feet; $\%$, percent]

\begin{tabular}{lcllll}
\hline & & $\begin{array}{l}\text { Median } \\
\text { nitrate } \\
\text { concen- } \\
\text { tration, } \\
\text { in mg/L } \\
\text { samples }\end{array}$ & $\begin{array}{l}\text { Percentage of } \\
\text { samples with } \\
\text { nitrate concen- } \\
\text { trations between } \\
3 \text { and 10 mg/L }\end{array}$ & $\begin{array}{l}\text { Percentage of } \\
\text { samples with } \\
\text { nitrate concen- } \\
\text { trations of at } \\
\text { least 10 mg/L }\end{array}$ & $\begin{array}{l}\text { Maximum } \\
\text { nitrate } \\
\text { concen- } \\
\text { tration, } \\
\text { in mg/L }\end{array}$ \\
\hline $\begin{array}{l}\text { All wells } \\
\text { Wells less than 200 ft deep }\end{array}$ & 36 & 4.0 & $44 \%$ & $14 \%$ & 19 \\
Wells at least 200 ft deep & 16 & 6.4 & $50 \%$ & $20 \%$ & 19 \\
\end{tabular}

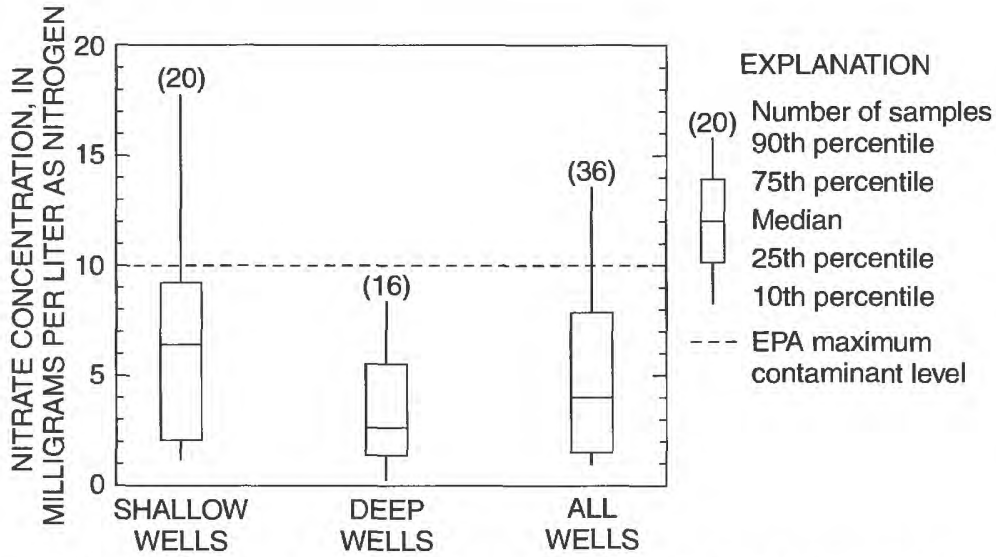

Figure 27a. The distribution of nitrate concentrations for groups of wells sampled in the Othello sampling region (categorized by ranges of well depths; see table 3 and table 25).

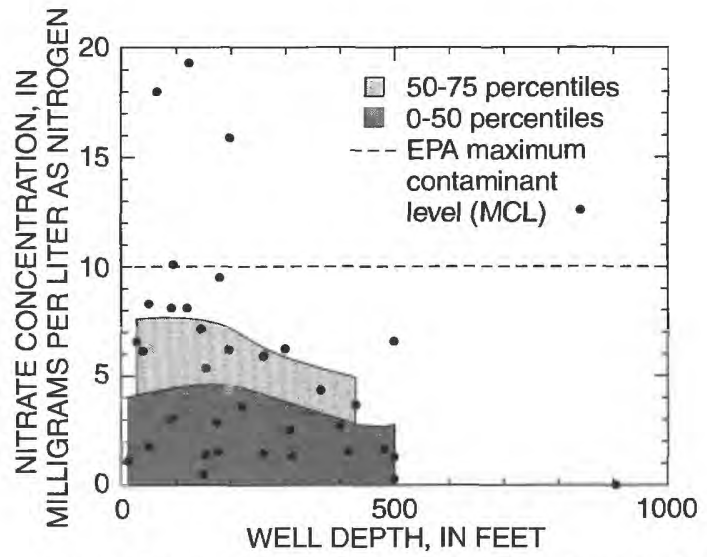

Figure 27b. Concentrations of nitrate in sampled wells, with lines representing moving 50 th and 75th percentiles of concentration for varying depths (estimated using the LOWESS method; see page 13). 


\section{Range}

The baseline dataset for the Range sampling region includes nine samples obtained during the fall 1998 sampling event. Summary statistics for both the shallow and deep well categories are highly uncertain due to the low number of samples obtained in each depth category (table 26).

Of the nine wells sampled in the Range sampling region, approximately 22 percent exceeded a nitrate concentration of $10 \mathrm{mg} / \mathrm{L}$. Unfortunately, due to the limited number of samples, it is difficult to state whether that is a representative value for the Range sampling region as a whole. The distribution of nitrate concentration versus well depth is shown in figure $28 \mathrm{~b}$. Insufficient data were available to compute boxplots for figure $28 \mathrm{a}$, or to draw LOWESS curves in figure $28 \mathrm{~b}$.

Table 26. Summary of nitrate concentrations in ground water, Range, Adams County [mg/L, milligrams per liter; $\mathrm{ft}$, feet; \%, percent]

\begin{tabular}{lcllll}
\hline & & $\begin{array}{l}\text { Median } \\
\text { nitrate } \\
\text { concen- } \\
\text { tration, } \\
\text { of } \\
\text { in mg/L }\end{array}$ & $\begin{array}{l}\text { Percentage of } \\
\text { samples with } \\
\text { nitrate concen- } \\
\text { trations between } \\
3 \text { and 10 mg/L }\end{array}$ & $\begin{array}{l}\text { Percentage of } \\
\text { samples with } \\
\text { nitrate concen- } \\
\text { trations of at } \\
\text { least 10 mg/L }\end{array}$ & $\begin{array}{l}\text { Maximum } \\
\text { nitrate } \\
\text { concen- } \\
\text { tration, } \\
\text { in mg/L }\end{array}$ \\
\hline $\begin{array}{l}\text { All wells } \\
\text { Wells less than 200 ft deep }\end{array}$ & 5 & 4.0 & $44 \%$ & $22 \%$ & 47 \\
Wells at least 200 ft deep & 3 & 4.1 & $40 \%$ & $40 \%$ & 47 \\
& 2.2 & $33 \%$ & $0 \%$ & 8.8 \\
\hline
\end{tabular}

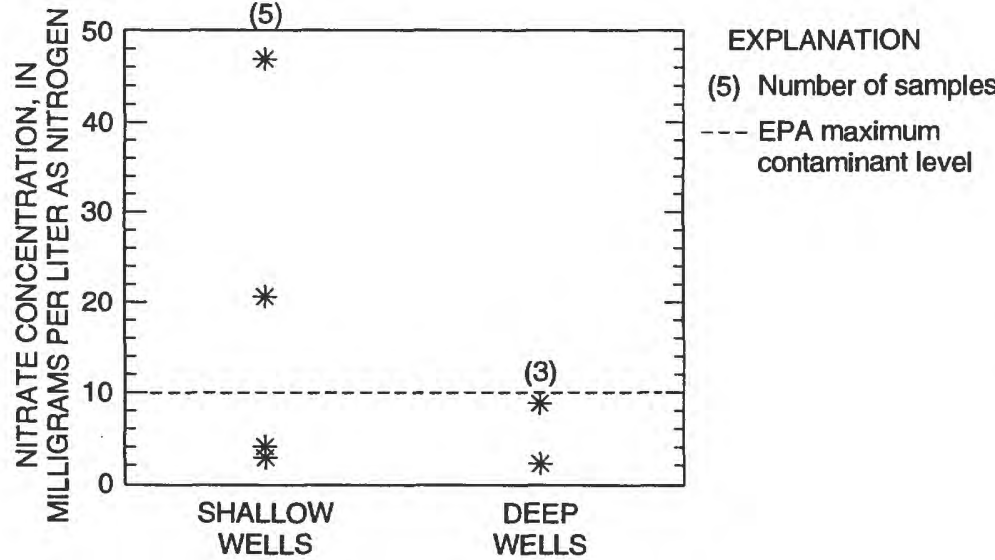

Figure 28a. The distribution of nitrate concentrations for groups of wells sampled in the Range sampling region (categorized by ranges of well depths; see tables 3 and 26). Insufficient data were available to compute boxplots for shallow and deep well categories, so individual data points are plotted.

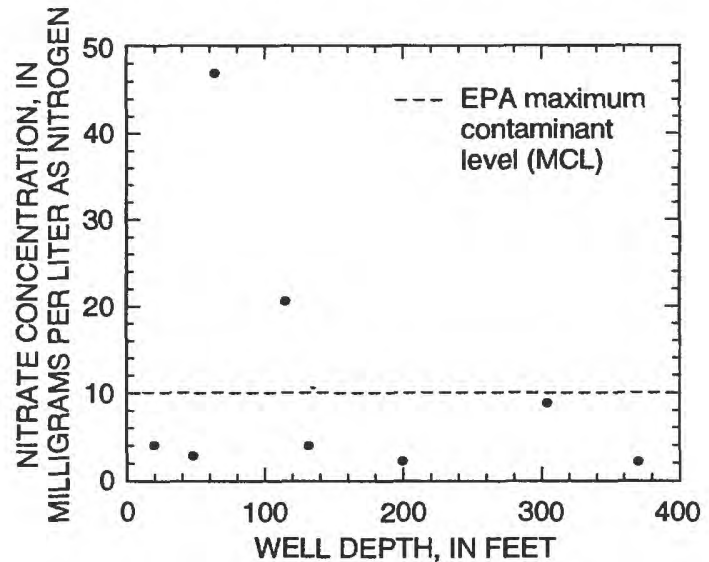

Figure 28b. Concentrations of nitrate in sampled wells. Insufficient data were available to draw LOWESS curves. 


\section{SUMMARY}

More than 80 percent of drinking water in the Columbia Basin, eastern Washington, comes from ground water. Since the onset of irrigation in the early 1950 's, nitrate concentrations in ground water in some areas of the Columbia Basin, eastern Washington, have increased greatly; at present, over 20 percent of sampled wells have nitrate concentrations exceeding drinking water standards. The Columbia Basin Ground Water Management Area (GWMA) was formed in February 1998 with the goal of reducing nitrate concentrations in ground water in Adams, Franklin, and Grant Counties.

As part of the GWMA characterization and monitoring program, 574 wells in Adams, Franklin, and Grant Counties were sampled for nitrate in the fall of 1998 . These wells serve as a baseline dataset of current nitrate concentrations in ground water in the GWMA area, and provide a basis for further research into agricultural practices and natural influences.

Summary statistics as well as the relation between nitrate concentration and depth were examined for 17 sampling regions within the three-county area. These summary statistics were computed for different ranges of well depths in each sampling region. Nitrate concentrations exceeded the U.S. Environmental Protection Agency maximum contaminant level (MCL) of 10 milligrams per liter of nitrate in drinking water in approximately 23 percent of the wells sampled. The highest rate was in Franklin County, with 30 percent of the samples exceeding the MCL, while in both Adams and Grant Counties approximately 20 percent of the samples exceeded the MCL. Across the whole GWMA area, approximately 37 percent of sampled wells had nitrate concentrations between 3 and $10 \mathrm{mg} / \mathrm{L}$, constituting a large group of wells with nitrate concentrations above naturally occurring levels but not exceeding the MCL. In most sampling regions, elevated concentrations of nitrate were found most frequently among shallow wells.

\section{REFERENCES CITED}

Alley, William, ed., 1993, Regional ground-water quality: New York, Van Nostrand Reinhold, 634 p.

Clesceri, L.S., Greenberg, A.E., and Eaton, A.D., eds., 1998, Standard methods for the examination of water and wastewater (20th ed.): Washington, DC, American Public Health Association, American Water Works Association, and Water Environment Federation, $1,134 \mathrm{p}$.

Columbia Basin Ground Water Management Area Characterization and Monitoring Workgroup, 23 April 1998, Decision on splitting characterization and monitoring tasks between private consultants and the U.S. Geological Survey: 3 p., 3 attachments.

Columbia Ground Water Management Area steering committee, 31 October 1997, Petition to designate a GWMA for Adams, Franklin, and Grant Counties: $13 \mathrm{p}$.

Drost, B.W., Cox, S.E., and Schurr, K.M., 1997, Changes in ground-water levels and ground-water budgets, from predevelopment to 1986, in parts of the Pasco Basin, Washington: U.S. Geological Survey Water-Resources Investigations Report 96-4086, 172 p., 1 pl

Ebbert, J.C., Cox, S.E., and Schurr, K.M., 1995, Distribution and sources of nitrate, and presence of fluoride and pesticides, in parts of the Pasco Basin, Washington, 1986-88: U.S. Geological Survey Water-Resources Investigations Report 93-4197, 173 p.

Fishman, J.J., 1993, Methods of analysis by the U.S. Geological Survey National Water Quality Laboratory-determination of inorganic and organic constituents in water and fluvial sediments: U.S. Geological Survey Open-File Report 93-125, 217 p.

Helsel, D.R., and Hirsch, R.M., 1992, Statistical methods in water resources: Amsterdam, Elsevier, $522 \mathrm{p}$.

Jones, J.L., and Wagner, R.J., 1995, Water-quality assessment of the Central Columbia Plateau in Washington and Idaho--analysis of available nutrient and pesticide data for ground water, 1942-92: U.S. Geological Survey Water-Resources Investigations Report 94-4258, $119 \mathrm{p}$.

Madison, R.J., and Brunett, J.O., 1985, Overview of the occurrences of nitrate in groundwater of the United States: U.S. Geological Survey Water Supply Paper 2275, p. 93-105.

Patton, C.J., and Gilroy, E.J., 1999, U.S. Geological Survey nutrient preservation experiment--experiment design, statistical analysis, and interpretation of analytical results: U.S. Geological Survey Water-Resources Investigations Report 98-4118, 73 p. 
Ryker, S.J., and Jones, J.L., 1995, Nitrate concentrations in ground water of the Central Columbia Plateau: U.S. Geological Survey Open-File Report 95-445, 4 p.

Scott, J.C., 1990, Computerized stratified random siteselection approaches for design of ground-waterquality sampling network: U.S. Geological Survey Water-Resources Investigations Report 90-4101, 109 p.

U.S. Environmental Protection Agency, 1993, Methods for determination of inorganic substances in environmental samples: U.S. Environmental Protection Agency EPA/600/R-93/100.

U.S. Geological Survey, 1999, The quality of our Nation's waters--nutrients and pesticides: U.S. Geological Survey Circular 1225, $82 \mathrm{p}$.
Washington State Interagency Ground Water Committee, 17 September 1996, A report on nitrate contamination of ground water in the Mid-Columbia Basin: Washington State Interagency Ground Water Committee Publication no. 96-17, approximately $20 \mathrm{p}$.

Washington Toxics Coalition and Washington State University Cooperative Extension, July 1994, Documented nitrate contamination in Washington: Washington Toxics Coalition and Washington State University Cooperative Extension EB1756d, 4 p. 


\section{APPENDIX A.--Results of quality-assurance sampling and analysis}


Table A1. Nitrate concentrations reported for split samples of well water

[WDOE, Washington Department of Ecology, USGS, U.S. Geological

Survey; concentrations in milligrams per liter; --, no data]

\begin{tabular}{|c|c|c|}
\hline $\begin{array}{l}\text { WDOE/Manchester } \\
\text { laboratory result }\end{array}$ & $\begin{array}{l}\text { Contract } \\
\text { laboratory result }\end{array}$ & $\begin{array}{l}\text { USGS/Denver } \\
\text { laboratory result }\end{array}$ \\
\hline$<0.01$ & 0.2 & -- \\
\hline 0.1 & 0.3 & -. \\
\hline$<0.01$ & 0.3 & -- \\
\hline 0.1 & 0.4 & -- \\
\hline 0.1 & 0.4 & - \\
\hline 0.9 & 1.0 & - \\
\hline 3.6 & 1.4 & -- \\
\hline 0.4 & 1.7 & - \\
\hline 4.1 & 3.5 & - \\
\hline 4.7 & 4.7 & -- \\
\hline 5.3 & 5.0 & - \\
\hline 7.0 & 6.3 & - \\
\hline 6.4 & 6.6 & -- \\
\hline 7.3 & 6.8 & - \\
\hline 7.8 & 7.0 & -- \\
\hline 7.5 & 7.0 & -- \\
\hline 9.4 & 8.4 & -- \\
\hline 10.3 & 9.9 & -- \\
\hline 12.6 & 11.3 & -. \\
\hline 13.1 & 12.0 & -- \\
\hline 12.7 & 12.2 & -- \\
\hline 15.7 & 13.9 & -- \\
\hline 20.6 & 16.9 & -- \\
\hline 23.2 & 20.3 & -- \\
\hline 25.0 & 22.1 & -- \\
\hline 30.3 & 25.9 & -- \\
\hline 38.2 & 33.3 & -- \\
\hline 83.8 & 70.5 & -- \\
\hline 20.0 & -- & 19.7 \\
\hline 19.8 & -- & 19.3 \\
\hline 27.2 & -- & 26.0 \\
\hline 2.3 & -- & 2.4 \\
\hline 5.8 & -- & 6.0 \\
\hline$<0.01$ & -- & $<0.05$ \\
\hline$<0.01$ & -- & 0.1 \\
\hline 11.3 & -- & 10.4 \\
\hline 5.1 & -- & 5.2 \\
\hline
\end{tabular}


Table A2. Nitrate concentrations reported for split samples of reference solutions

[WDOE, Washington Department of Ecology; USGS, U.S. Geological Survey; concentrations in milligrams per liter]

Most probable value (concentration) of reference solution prepared by USGS/Ocala laboratory

WDOE/Manchester

laboratory result

Contract
laboratory
result

Contract
laboratory
result

USGS/Denver

laboratory

result

\begin{tabular}{rrrr}
\hline & & & \\
0.9 & 1.0 & 1.3 & 0.91 \\
0.9 & 0.8 & 1.2 & 0.9 \\
9.7 & 9.0 & 7.2 & 9.5 \\
9.7 & 8.8 & 7.4 & 9.5 \\
10.0 & 9.0 & 7.3 & 9.6 \\
18.5 & 16.6 & 14.5 & 17.6 \\
18.5 & 16.8 & 14.6 & 17.8 \\
18.5 & 16.9 & 15.0 & 17.9 \\
\hline
\end{tabular}

